\title{
Die struktuur van die linker-sinsgrens in Afrikaans*
}

\author{
Morné Botha en Johan Oosthuizen \\ Departement Algemene Taalwetenskap, Universiteit van Stellenbosch, 7600 Stellenbosch, Suid-Afrika \\ E-mail: jo@sun.ac.za
}

\section{Inleiding}

Die funksionele kategorie komplementeerder ("complementizer", C(omp)) en sy projeksies C' en CP het ' $\mathrm{n}$ sentrale rol gespeel in die ontwikkeling van generatiewe sintaksis sedert die vroeë 1970's. Die aanvanklike voorstelle van, onder meer, Bresnan (1970, 1974, 1977), Chomsky (1972), Den Besten (1977), Emonds (1976) en Jackendoff (1977) het ingehou dat daar ' $\mathrm{n}$ frase-kategorie, bekend as S-balk ("S-bar"), gepostuleer word wat die C en die S direk domineer. S-balk is mettertyd binne die raamwerk van die X-balk-teorie heranaliseer as die maksimale projeksie $\mathrm{CP}$ van die funksionele hoofkategorie $\mathrm{C}$, met die frase-kategorie $\mathrm{C}^{\prime}$ tussen die $\mathrm{C}$ en die CP. Die funksie van die CP-domein was tweeledig. Enersyds het die spesifiseerderposisie onder die CP 'n landingsplek beskikbaar gestel vir vooropgestelde whfrases en gefokaliseerde frases. Andersyds het die $\mathrm{C}$ self 'n strukturele posisie gebied vir sinsinleidende elemente soos dat ("that") en of ("whether", "if"), asook vir werkwoorde wat vooropgestel is in die afleiding van byvoorbeeld ja/nee-vraagsinne.

Benewens die sintaktiese motivering vir die $\mathrm{CP}$, is daar ook semantiese en diskoerspragmatiese evidensie aangebied vir so 'n formele domein; kyk byvoorbeeld Hoekstra \& Zwart (1994) en Rizzi (1997). Die basiese idee was dat die CP-domein optree as 'n soort koppelvlak tussen die sin as sintaktiese objek en die diskoers-pragmatiese konteks waarin dit geuiter word. As inleier van 'n sin het die $\mathrm{C}$ byvoorbeeld die sinstipe gespesifiseer (stelsin of 
vraagsin) deur ' $\mathrm{n}$ formele kenmerk soos $[ \pm \mathrm{Q}]$ (of $[ \pm \mathrm{WH}]$ ). Verder is voorgestel dat semantiespragmatiese onderskeidings soos dié tussen topiek ("bekende inligting") en fokus ("nuwe inligting") ook uitgedruk word binne die CP-domein.

Veral sedert die laat 1980's is sintaktiese ondersoek binne die generatiewe benadering gekenmerk deur toenemend ryker en meer gedifferensieerde beskrywings van die struktuur van funksionele kategorieë. Hoekstra \& Zwart (1994:191) stel dit dat "in de generatiewe taalkunde zijn de meest spectaculaire resultaten te danken geweest aan het aannemen van een rijkere structuur." Hierdie tendens is ingelui deur die invloedryke studies van Abney (1987) en Pollock (1989). Abney se voorstel - die sogenaamde DP-hipotese - hou in dat alle nominale uitdrukkings beskryf word as projeksies van 'n funksionele kategorie D ("determiner"), waar so 'n kategorie 'n NP as komplement kan selekteer. ${ }^{1}$ Pollock se voorstel bekend as die Verdeelde-IP-hipotese ("Split-IP hypothesis") - behels die analise van die Infleksie-frase (IP, sedertdien bekend as Tempusfrase, TP) as 'n kluster van minstens drie verskillende funksionele hoofde, elk met hul eie frase-projeksies: AgrS ("Agreementsubject"), T ("Tense") en AgrO ("Agreement-object"). Hierdie twee hipoteses word albei in die een of ander vorm aanvaar in onlangse sintaktiese ondersoek; beide geniet empiriese ondersteuning en maak taalkundig betekenisvolle voorspellings oor woordordevariasies tussen tale.

Die verryking van sintaktiese struktuur deur die postulering van toenemend meer funksionele hoofde het in die 1990's gelei tot 'n spesifieke benadering tot sintaktiese ondersoek, die sogenaamde kartografiese benadering ("cartographic approach"). Rizzi (2004:3) maak die volgende opmerkings in hierdie verband:

Much theory guided descriptive work on syntactic constituents over the 1980s and 1990s has shown that phrases and clauses have a richly articulated internal structure. As the empirical evidence of such complexity had been steadily accumulating, some researchers came to the conclusion that it was a worthwhile endeavor to study this rich domain on its own.

Teen hierdie agtergrond ontstaan die vraag nou of die konvensionele beskrywing van die CPdomein ook 'n meer komplekse realiteit omvat. Met ander woorde, is daar enige bewyse wat 
daarop dui dat die projeksie CP, soos in die geval van die NP en die IP/TP, verdeel kan word in verdere, afsonderlike projeksies, elk met sy eie funksionele hoof?

Een van die eerste sistematiese pogings om die CP-domein te analiseer binne die raamwerk van die kartografiese benadering het neerslag gevind in Rizzi (1997) se Verdeelde-CPhipotese. ${ }^{2}$ 'n Sentrale uitgangspunt van hierdie hipotese is dat die diskoers-pragmatiese oriëntering van sinne struktureel uitgedruk word binne die CP-domein. Gevolglik postuleer Rizzi (1997:297) dat die enkele C-hoof in vier afsonderlike funksionele hoofde verdeel word, elk met sy eie projeksie: Topiek ("Topic"), Fokus ("Focus"), Krag ("Force"), en Finietheid ("Finiteness"). Rizzi (2004:4) gee die volgende algemene motivering vir hierdie verdeling:

Clauses should be the articulation of lexical and functional elements, each projecting uniform subtrees according to the general laws of structure building ... clauses should be formed by a constant system of functional heads in all languages, each projecting a subtree occurring in a fixed syntactic hierarchy.

Hierdie artikel fokus op die interne struktuur van die CP in Afrikaans, in Rizzi (1997:281) se woorde, "the fine structure of the left periphery". Hoewel Rizzi se Verdeelde-CP-hipotese as uitgangspunt dien in die bespreking van die fyn struktuur van die linker-sinsgrens, word daar ook aandag gegee aan meer onlangse voorstelle van Beninca' \& Poletto (2004) in hierdie verband. Die oogmerk van die artikel is om vas te stel of Rizzi (1997) en Beninca' \& Poletto (2004) se voorstelle ook geld vir die beskrywing van die CP-domein in Afrikaans. In meer spesifieke terme is die oogmerk om antwoorde te kry op die volgende vrae:

A. Bied die Verdeelde-CP-hipotese 'n toereikende raamwerk vir die beskrywing van die CP-domein in Afrikaans?

B. Indien nie, hoe sou (spesifieke onderdele van) hierdie hipotese aangepas kon word om die feite van Afrikaans te akkommodeer?

Die studie word aangebied binne die teoretiese raamwerk van Minimalistiese Sintaksis, die mees onlangse teorie van grammatika binne die Beginsels en Parameters-benadering tot taalondersoek. Enkele sentrale aannames en meganismes van Minimalistiese Sintaksis word in afdeling 2 uiteengesit en geïllustreer met verwysing na Afrikaanse voorbeelde. Afdeling 3 
fokus op die interne struktuur van die CP-domein. Eerstens word kortliks aandag gegee aan Hoekstra \& Zwart (1994) se aanvanklike voorstelle vir die verdeling van die C in twee afsonderlike hoofde, naamlik Wh en Topiek. Vervolgens word Rizzi (1997) se Verdeelde-CPhipotese asook Beninca' \& Poletto (2004) se latere aanpassings van hierdie hipotese uiteengesit en krities bespreek aan die hand van Afrikaanse data. In die loop van die bespreking word enkele wysigings gesuggereer om die (aangepaste) Verdeelde-CP-hipotese versoenbaar te maak met potensieel problematiese Afrikaanse data. Afdeling 4 gee 'n samevatting van die vernaamste bevindings van die ondersoek, spesifiek van die meriete van Rizzi (1997) en Beninca' \& Poletto (2004) se voorstelle as 'n raamwerk vir die beskrywing van die interne struktuur van die CP in Afrikaans. Ten slotte word daar ook aandag gegee aan drie potensieel problematiese kwessies in Afrikaans wat verdere ondersoek verg.

\section{Teoretiese raamwerk}

\section{$2.1 \quad$ Inleiding}

In die laat 1970's het 'n belangrike konseptuele verskuiwing plaasgevind in Chomskyaanse generatiewe sintaksis. Die raamwerk van aannames wat gespruit het uit hierdie verskuiwing staan bekend as die Beginsels en Parameters ("Principles \& Parameters", P\&P)-benadering tot Universele Grammatika. Die sintaktiese teorie wat binne dié raamwerk ontwikkel is, naamlik die Regeer-en-Bind ("Government \& Binding", GB)-teorie, was sonder twyfel die mees invloedryke en produktiewe teorie van sinstruktuur gedurende die 1980's en vroeë-1990's. Die teorie het aanleiding gegee tot analises van buitengewone verklarende diepte, nie net in sinchroniese sintaksis nie, maar ook in sulke diverse studievelde soos, onder meer, eerste- en tweedetaalverwerwing, kodewisseling, taalverandering, taalagteruitgang, en pidgin- en kreoolstudies.

Dit het egter geleidelik duidelik geword dat GB-teorie mank gaan aan verskeie ernstige empiriese en konseptuele probleme. Veral in die lig van die konseptuele probleme, het 'n alternatiewe benadering - hoewel steeds binne dieselfde P\&P-raamwerk as GB-teorie - sedert die begin-1990's begin vorm aanneem. Die ontwikkeling van hierdie alternatiewe benadering, sedertdien bekend as Minimalistiese Sintaksis (MS), was 'n direkte uitvloeisel van werk wat gedoen is binne die Minimalistiese Program (MP), 'n stimulerende linguistiese navorsingsprogram wat in daardie tyd voorgestel is en wat steeds rigtinggewend is vir navorsing in 
verskeie studievelde. Hoewel MP nie ('n raamwerk vir) 'n teorie van grammatika is nie, opper dit tog interessante vrae oor die ontwerp van die menslike taalfakulteit en sy verhouding met ander kognitiewe stelsels van die gees/brein. Soos Chomsky (1995:1) dit stel:

This work is motivated by two related questions: (1) what are the general conditions that the human language faculty should be expected to satisfy? and (2) to what extent is the language faculty determined by these conditions, without special structure that lies beyond them? The first question in turn has two aspects: what conditions are imposed on the language faculty by virtue of (A) its place within the array of cognitive systems of the mind/brain, and (B) general considerations of conceptual naturalness that have some independent plausibility, namely, simplicity, economy, symmetry, non-redundancy, and the like?

In 'n poging om die probleme op te los wat spruit uit hierdie vrae, is talle (sub)teorieë binne die raamwerk van MS ontwikkel. Daar moet egter op gelet word dat verskeie van dié (sub)teorieë alternatiewe benaderings tot 'n gegewe probleem verteenwoordig, wat dikwels in nie-triviale opsigte van mekaar verskil. MS is dus in 'n hoë mate 'n voortgaande ontwikkeling. Hieronder volg ' $n$ bondige uiteensetting van enkele sentrale aannames en meganismes van MS, toegelig aan die hand van Afrikaanse voorbeelde. ${ }^{3}$

\subsection{Organisasie van die grammatika}

Binne MS bestaan ' $n$ taal uit 'n leksikon en 'n komputasie-sisteem. Die leksikon is ' $n$ versameling items (woorde, morfeme, funksionele elemente, ens.), elkeen voorgestel as 'n bundel kenmerke. Die funksie van die komputasie-sisteem is om dié items te kombineer tot uitdrukkings wat sowel foneties as semanties interpreteerbaar is. Sulke interpretasies word bewerkstellig in twee afsonderlike kognitiewe sisteme, naamlik die Konseptueel-Intensionele (K-I)-sisteem en die Artikulatories-Perseptuele (A-P)-sisteem. A-P is verantwoordelik vir die fonetiese interpretasie en K-I vir die semantiese interpretasie van 'n uitdrukking. Die komponent van die komputasie-sisteem wat met A-P in wisselwerking is, staan bekend as Fonetiese Vorm (PF), en dié wat met K-I in wisselwerking is, staan bekend as Logiese Vorm (LF). PF en LF verteenwoordig dus koppelvlakke tussen die komputasie-sisteem en ander kognitiewe sisteme. 'n Sentrale vraag binne MS is tot watter mate die taalsisteem optimaal voldoen aan die vereistes wat deur die K-I- en A-P-sisteme gestel word. Anders gestel, aan 
watter koppelvlakvoorwaardes ("interface conditions") moet die taalsisteem optimaal voldoen? 'n Basiese aanname binne MS is dat sulke voorwaardes gedefinieer moet word in terme van oorwegings soos ekonomie en eenvoud. 'n Verdere aanname, uitgedruk deur die Uniformiteitsvoorwaarde ("Uniformity Condition"), is dat dieselfde soort meganismes en bewerkings vir beide die PF- en LF-komponente beskikbaar moet wees (Hornstein et al. 2005:68).

Binne MS begin die afleiding van 'n uitdrukking met 'n skikking ("Numeration", voortaan $\mathrm{Nmr}$ ), 'n stel items wat gekopieer word uit die leksikon. Die komputasie-sisteem gebruik die elemente van Nmr as toevoer en lewer sintaktiese objekte, dit wil sê, kombinasies van leksikale items, as produk (Adger 2003:142). In die afleiding van 'n uitdrukking moet al die elemente van Nmr gebruik word vir die afleiding om geslaagd te wees. ${ }^{4}$ 'n Verdere beperking, bekend as die Insluitingsvoorwaarde ("Inclusiveness Condition"), is dat die elemente van Nmr die enigstes is wat in 'n afleiding gebruik mag word. Geen nuwe inligting, soos byvoorbeeld indekse, balk-vlakke ("bar-levels"), spore ("traces"), ens. mag dus in die loop van die afleiding toegevoeg word nie.

Die kenmerke waaruit leksikale items opgebou is, word in drie algemene tipes verdeel: fonetiese kenmerke wat 'n rol speel in die fonetiese interpretasie van die uiting, semantiese kenmerke wat geïnterpreteer moet word deur die K-I-sisteem, en formele (of grammatikale) kenmerke wat geassosieer word met byvoorbeeld kasus, tempus, persoon, getal, sintaktiese kategorie, ens. 'n Leksikale item soos byvoorbeeld loop is dus 'n kompleks van fonetiese kenmerke wat spesifiseer wat die klankvorm van die woord is, semantiese kenmerke wat die betekenis van die woord verteenwoordig, en formele kenmerke wat onder meer die kategorie $\mathrm{V}$ spesifiseer, die tempusvorm, en die betrokke getal- en persoonseienskappe (algemeen bekend as phi $(\varphi)$-kenmerke). Formele kenmerke is die lokus waar parametriese variasie tussen tale uitgedruk kan word. Tale kan onder meer verskil deurdat sulke kenmerke foneties gerealiseer word of nie. In Afrikaans, byvoorbeeld, word kasuskenmerke slegs gerealiseer op voornaamwoorde, terwyl sulke kenmerke in Duits overt weergegee word op voornaamwoorde, (sommige) naamwoorde, adjektiewe en determineerders ("determiners"). In Engels word tempus- en $\varphi$-kenmerke foneties gerealiseer op werkwoorde, maar nie in Afrikaans nie. 
Leksikale items bestaan verder uit twee tipes, naamlik funksionele items en substantiewe items. Funksionele items (byvoorbeeld T(empus), D(etermineerder), komplementeerder (C), klein- $v$, ens.) bevat formele kenmerke wat in die loop van die afleiding afgemerk ("checked") moet word; sulke items bevat nie semantiese kenmerke nie en dikwels ook nie fonetiese kenmerke nie. Daarteenoor bevat substantiewe items, byvoorbeeld naamwoorde $(\mathrm{N})$, werkwoorde (V), adjektiewe (A) en preposisies (P), wel semantiese en fonetiese kenmerke. In teenstelling met vroeëre versies van generatiewe sintaksis, word daar binne MS aangeneem dat ook formele kenmerke reeds teenwoordig is by substantiewe leksikale items wanneer hulle gekopieer word in die samestelling van Nmr. Dit beteken dat, byvoorbeeld, 'n naamwoord reeds in Nmr ' $\mathrm{n}$ kasuskenmerk bevat, en dit nie eers in die loop van die afleiding toegeken word nie. 'n Finiete werkwoord bevat eweneens sy tempuskenmerk reeds in Nmr.

Die skikking Nmr van 'n sin soos Jan soen haar kan vereenvoudig soos in (1) voorgestel word; die onderskrif spesifiseer telkens hoeveel keer elke item gebruik moet word in die afleiding.

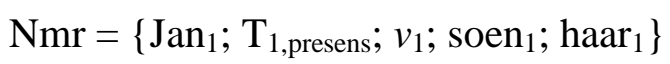

'n Skikking vorm die toevoer vir Saamvoeg ("Merge"), ${ }^{5}$ 'n konseptueel noodsaaklike meganisme wat verantwoordelik is vir die opbou van frases. Algemeen gestel: Saamvoeg selekteer twee items en kombineer hulle tot een nuwe sintaktiese objek. Saamvoeg vorm die basis van die rekursiewe eienskap van taal omdat daar in beginsel geen beperking is op hoeveel keer dit mag toepas nie. Die enigste beperking is dat Saamvoeg al die elemente van 'n gegewe Nmr moet gebruik.

Saamvoeg kan verdeel word in twee tipes, naamlik Eksterne-Saamvoeg (ES) en InterneSaamvoeg (IS) ("External Merge" en "Internal Merge"). ${ }^{6}$ ES, aan die een kant, hou in dat (slegs) twee elemente gekombineer word; dié bewerking bring mee dat 'n nuwe sintaktiese objek gevorm word, met as toevoer 'n element uit Nmr wat gekombineer word óf met ' $\mathrm{n}$ ander element uit Nmr óf met 'n sintaktiese objek wat reeds vroeër deur 'n toepassing van ES gevorm is. Die bewerking wat uitgevoer word deur ES is onderhewig aan die Peuterverbod ("No Tampering Condition") wat inhou dat die twee items wat gekombineer word se onderskeie kenmerke onveranderd moet bly in die betrokke bewerking. IS, aan die ander kant, 
hou in dat 'n onderdeel van 'n sintaktiese objek gekopieer word en in die spesifiseerderposisie van daardie objek saamgevoeg word. In hierdie geval, dus, word geen nuwe sintaktiese objek gevorm nie en word geen element uit Nmr geselekteer nie. Die bewerking wat uitgevoer word deur IS stem in 'n mate ooreen met die soort bewerking wat in vroeëre versies van die teorie uitgevoer is deur skuifprosesse soos Skuif NP en Skuif Wh-frase.

Die motivering vir die toepassing van IS hang saam met die interpreteerbaarheid van formele kenmerke, onder meer die formele kenmerke van funksionele kategorieë. 'n Sentrale beginsel binne MS is dié van Volle Interpretasie ("Full Interpretation"). Volgens hierdie beginsel moet alle kenmerke in 'n afleiding interpreteerbaar wees in die PF- en LF-komponente. Enige oninterpreteerbare kenmerke op PF of LF bring mee dat die afleiding op die betrokke koppelvlak ineenstort ("crash"); daarteenoor konvergeer 'n afleiding indien al die betrokke kenmerke op onderskeidelik PF en LF interpreteerbaar is. Aangesien funksionele hoofde die draers van oninterpreteerbare formele kenmerke is, moet hierdie kenmerke in die loop van die afleiding afgemerk en gedeleer word vir die afleiding om te konvergeer. Soos Adger (2003:167) dit stel, "uninterpretable features must be checked, and once checked, they can delete."

Die afmerking en gepaardgaande delesie van formele kenmerke word bewerkstellig deur Kongrueer ("Agree"), 'n bewerking wat 'n oninterpreteerbare kenmerk afpaar met 'n ooreenstemmende interpreteerbare kenmerk; in so 'n konfigurasie word eersgenoemde kenmerk dan gedeleer. Byvoorbeeld, deur middel van Kongrueer word die oninterpreteerbare tempuskenmerk van die $\mathrm{T}$ afgepaar met die interpreteerbare tempuskenmerk van 'n finiete werkwoord, waarna die kenmerk van die T gedeleer word. In sommige tale moet dié soort afparing in 'n lokale domein plaasvind, 'n verskynsel wat uitgedruk word deur die aanname dat die betrokke kenmerk van die funksionele kategorie in PF-terme"sterk" is. Dit beteken dat, in sulke tale, die item met die interpreteerbare kenmerk "aangetrek" word deur die draer van die sterk kenmerk; sodanige aantrekking dwing die toepassing van IS af. Indien die finiete werkwoord en die T dus nie in dieselfde lokale domein voorkom nie - dit wil sê, "te ver" van mekaar is in strukturele terme - word die werkwoord deur IS geadjungeer aan die T. IS word dus gedryf deur die vereiste dat oninterpreteerbare kenmerke gedeleer moet word in die loop van die afleiding. Die parameter wat spesifiseer of 'n gegewe kenmerk "sterk" of "swak" is, en dus IS afdwing of nie, vorm die basis van woordordevariasie tussen tale. 
Op spesifieke stadiums in 'n afleiding word daardie kenmerke wat 'n rol speel in die PFrepresentasie van 'n uitdrukking geskei van dié wat ' $n$ rol speel by die LF-representasie, dit wil sê, die representasie wat semanties deur die K-I-sisteem geïnterpreteer moet word. 'n Stadium waarop spesifieke kenmerke geskei word van mekaar en afgevoer word na onderskeidelik die PF- en die LF-komponent, staan bekend as 'n Fase ("Phase"); in MS word minstens die komplemente van $v \mathrm{P}$ en $\mathrm{CP}$ as fases voorgestel.

Die organisasie van die grammatika kan ter samevatting skematies soos volg voorgestel word:

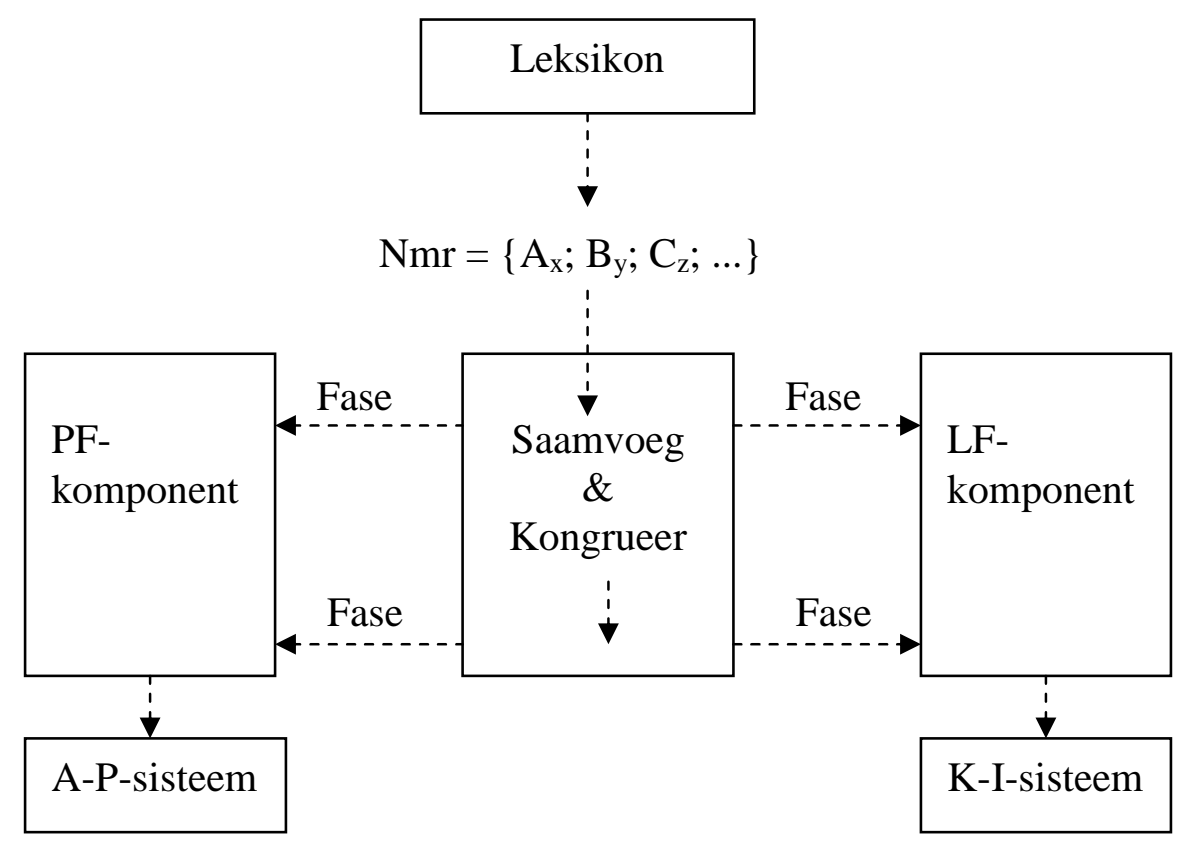

\subsection{Enkele afleidings}

In hierdie afdeling word die afleiding van vier konstruksies in Afrikaans geïllustreer binne die raamwerk van aannames en meganismes wat uiteengesit is in afdeling 2.2. In elke geval strek die afleiding slegs tot by die bewerking wat die TP tot stand bring; met ander woorde, die afleiding word nie gevoer tot by die generering van die CP nie. Die rede hiervoor is dat die interne struktuur van die CP die fokus van afdeling 3 vorm.

Ter aanvang is dit nodig om kortliks aandag te gee aan drie hipoteses wat sentraal is in die afleiding van sinne. Die eerste betref die funksionele kategorie klein-v (voortaan $v$ ). Binne MS word gepostuleer dat werkwoordelike frases 'n "dubbele struktuur" vertoon, die sogenaamde 
VP-skulphipotese ("VP-shell Hypothesis"). ${ }^{7}$ Dié hipotese maak dit moontlik om die tematiese struktuur van 'n sin te beskryf in terme van (slegs) die strukturele verhoudings "komplement van" en "spesifiseerder van". Die tweede hipotese, die Uniforme Theta-toekenningshipotese ("Uniform Theta Assignment Hypothesis", UTAH), hou in dat dieselfde tematiese verhoudings sintakties deur dieselfde strukturele verhoudings voorgestel word, waar laasgenoemde tot stand gebring word deur ES. ${ }^{8}$ Dus moet die aanvanklike strukturele konfigurasie van 'n sin presies ooreenstem met die tematiese organisasie daarvan. Binne die raamwerk van 'n VP-skulpanalise is die heel boonste laag (dit wil sê, die hoogste in boomdiagramterme) van 'n werkwoordelike frase die $v \mathrm{P}$ (klein $v$-frase). 'n Leksikale $\mathrm{V}$ (geprojekteer as VP) vorm voorts die komplement van $v$, die hoof van $v$ P. Klein- $v$ verteenwoordig 'n "ligte werkwoord" wat geen fonetiese inhoud het nie, ${ }^{9}$ maar wat wel 'n theta $(\theta)$-rol aan die subjek van die sin kan toeken, ${ }^{10}$ die leksikale V, op sy beurt, ken 'n $\theta$-rol toe aan die objek en enige ander argumente wat met die $\mathrm{V}$ geassosieer is.

Die derde hipotese is die Predikaat-interne Subjekhipotese ("Predicate Internal Subject Hypothesis", PISH). Volgens die PISH vorm die $v \mathrm{P}$ se spesifiseerderposisie die anvanklike posisie waar die subjek van 'n sin deur ES gegenereer word; anders as in vorige raamwerke, staan die subjek dus nie van die begin af in die spesifiseerderposisie van die TP (of IP) nie. ${ }^{11}$ Soos gemeld, verskaf $v$ 'n $\theta$-rol aan die subjek; in die geval van 'n agentiewe $v$, byvoorbeeld, sal dit die Agent-rol wees. 'n Belangrike eienskap van $v$ is dat dit 'n sterk V-kenmerk bevat, dit wil sê, 'n formele kenmerk wat op PF oninterpreteerbaar is tensy dit fonetiese inhoud verkry. Dié kenmerk bring mee dat die leksikale $\mathrm{V}$ verplig na $v$ toe moet verskuif en daarmee moet saamsmelt. Soos Hornstein et al. (2005:92) dit stel, "The light verb and its complement may thus be understood as forming a kind of complex predicate." Met "verskuif" word bedoel die bewerking wat deur IS uitgevoer word, dit wil sê, kopiëring van V en die daaropvolgende saamvoeging met $v$.

Die vier konstruksies wat hieronder bespreek word, is (i) die oorganklike konstruksie, (ii) die ditransitiewe konstruksie, (iii) die onakkusatiewe konstruksie en (iv) die onergatiewe konstruksie. Beskou eerstens die oorganklike konstruksie, soos geïllustreer deur die sin in (3). ${ }^{12}$

(3) Jan soen haar. 
Die eerste stap in die afleiding van dié sin is om die betrokke items uit die leksikon te kopieer; dit lewer die Nmr in (4).

(4) $\mathrm{Nmr}=\left\{\operatorname{Jan}_{1} ;\right.$ haar $\left._{1} ; \operatorname{soen}_{1} ; v_{\text {agentief } 1} ; \mathrm{T}_{\text {presens } 1}\right\}$

Deur die toepassing van ES word die V soen met die objek DP haar saamgevoeg om 'n VP te vorm, soos weergegee in (5). In hierdie konfigurasie word die $\theta$-rol van Tema met die DP geassosieer. $^{13}$

(5)

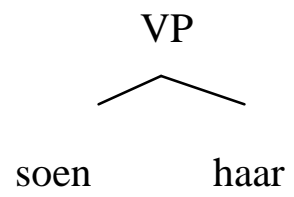

Die volgende stap is om die agentiewe $v$ in (4) deur middel van ES saam te voeg met die VP, met $v \mathrm{P}^{1}$ as resultaat. ${ }^{14}$ Hierna bring IS die saamvoeging mee van die leksikale $\mathrm{V}$ en die $v$ om 'n komplekse $v$-predikaat te vorm. Soos aangedui in (6) word die subjek DP Jan en $v \mathrm{P}^{1}$ deur ES saamgevoeg om $v \mathrm{P}^{2}$ te vorm, 'n konfigurasie waarin die DP die $\theta$-rol van Agent ontvang. ${ }^{15}$

(6)

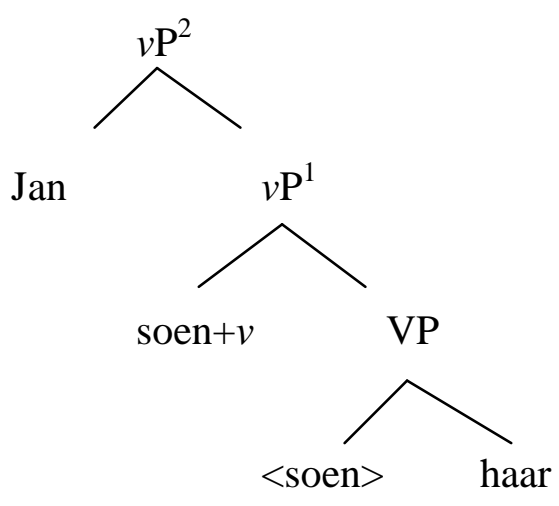

Die objek DP word vervolgens deur IS geskuif ${ }^{16}$ na die (tweede) spesifiseerderposisie van die $v$ om $v \mathrm{P}^{3}$ te vorm, weergegee in (7). ${ }^{17}$ 
(7)

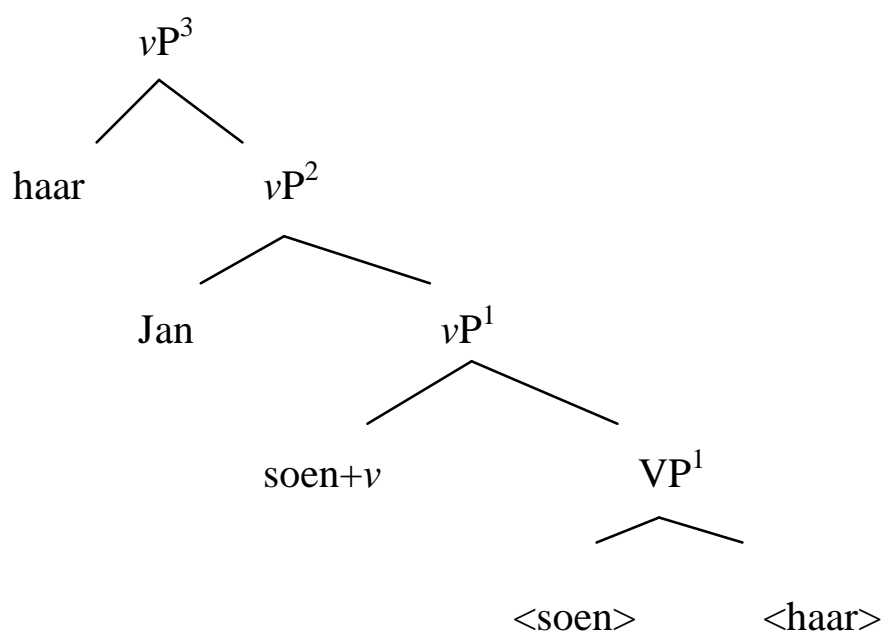

Die $\mathrm{T}$ in (4) word nou saamgevoeg met die hoogste $v$-projeksie, in hierdie geval $v \mathrm{P}^{3}$, om $\mathrm{TP}^{1}$ te vorm. Hierna volg twee IS-bewerkings. Enersyds word die subjek-DP geskuif na die spesifiseerderposisie van die $\mathrm{T}$ om $\mathrm{TP}^{2}$ te vorm; die rede vir dié bewerking is dat die $\mathrm{T}$ 'n oninterpreteerbare D-kenmerk bevat (vgl. die Uitgebreide Projeksiebeginsel, "Extended Projection Principle") wat deur die subjek-DP afgemerk moet word. ${ }^{18}$ Andersyds word die komplekse $v$-predikaat soen (dit wil sê, V soen + agentiewe v) geskuif na die hoof T self; die rede vir dié bewerking is dat die $\mathrm{T}$ 'n oninterpreteerbare tempuskenmerk bevat wat deur die komplekse $v$ afgemerk moet word. Die twee bewerkings word weergegee in (8) hieronder.

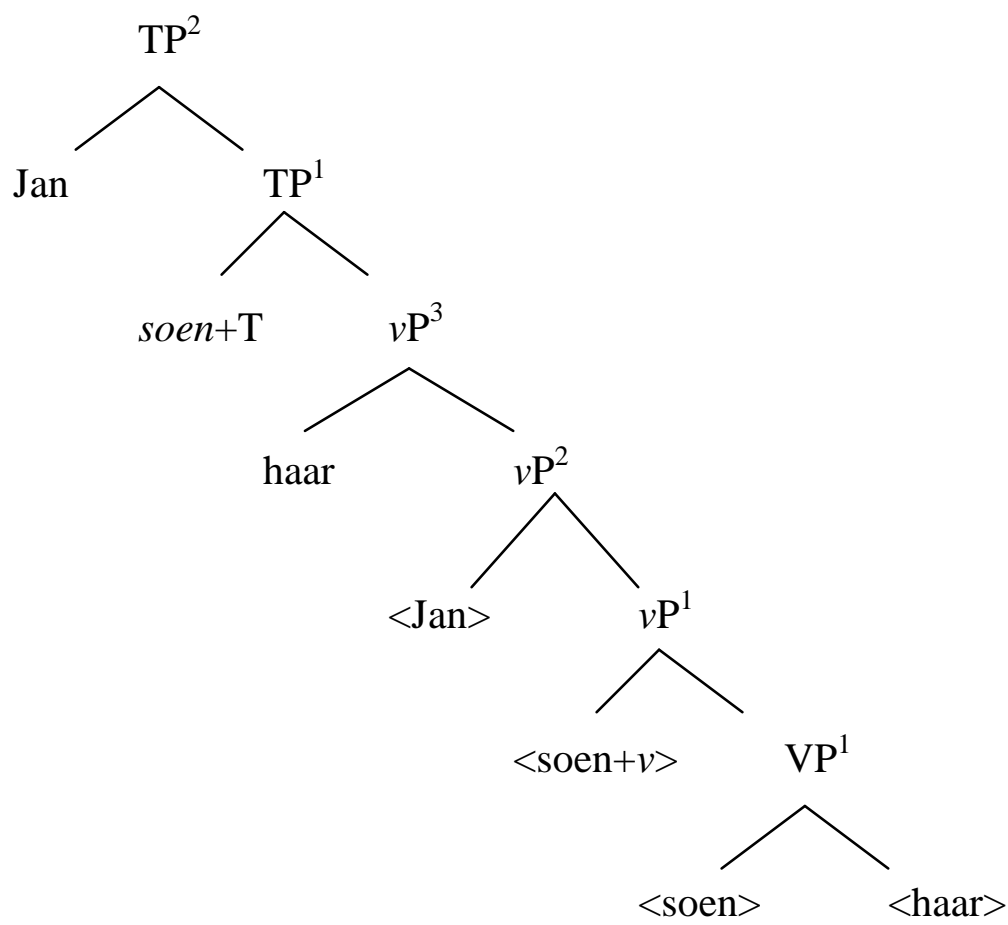


Beskou tweedens die afleiding van 'n ditransitiewe konstruksie soos geïllustreer deur die sin in (9). ${ }^{19}$ Die skikking vir (9) kan voorgestel word soos in (10).

(9) Rooiwyn gee hom jig.

(10) $\mathrm{Nmr}=\left\{\right.$ rooiwyn $_{1} ; \mathrm{T}_{\text {presens } 1} ; v_{\text {agentatief } 1} ;$ gee $_{1} ;$ hom $\left._{1} ; \mathrm{jig}_{1}\right\}$

Die afleiding van sin (9) verloop stapsgewys soos volg:

i. $\quad$ ES van die $\mathrm{V}$ gee en die $\mathrm{D}$ jig lewer $\mathrm{VP}^{1}$;

ii. $\quad$ ES van die DP hom in die spesifiseerderposisie van die V lewer $\mathrm{VP}^{2}$;

iii. $\quad$ ES van die $v$ met $\mathrm{VP}^{2}$ lewer $v \mathrm{P}^{1}$;

iv. IS van die $\mathrm{V}$ met die $v$ lewer die komplekse $v$-predikaat;

v. $\quad$ ES van die DP rooiwyn in die spesifiseerderposisie van die $v$ lewer $v \mathrm{P}^{2}$;

vi. IS van die DP jig in die tweede spesifiseerderposisie van die $v$ lewer $v \mathrm{P}^{3}$ (om die komplekse $v$ se kasuskenmerk af te merk);

vii. IS van die DP hom in die derde spesifiseerderposisie van die $v$ lewer $v \mathrm{P}^{4}{ }^{20}$

Die resultaat van stappe (i-vii) word geïllustreer in diagram (11).

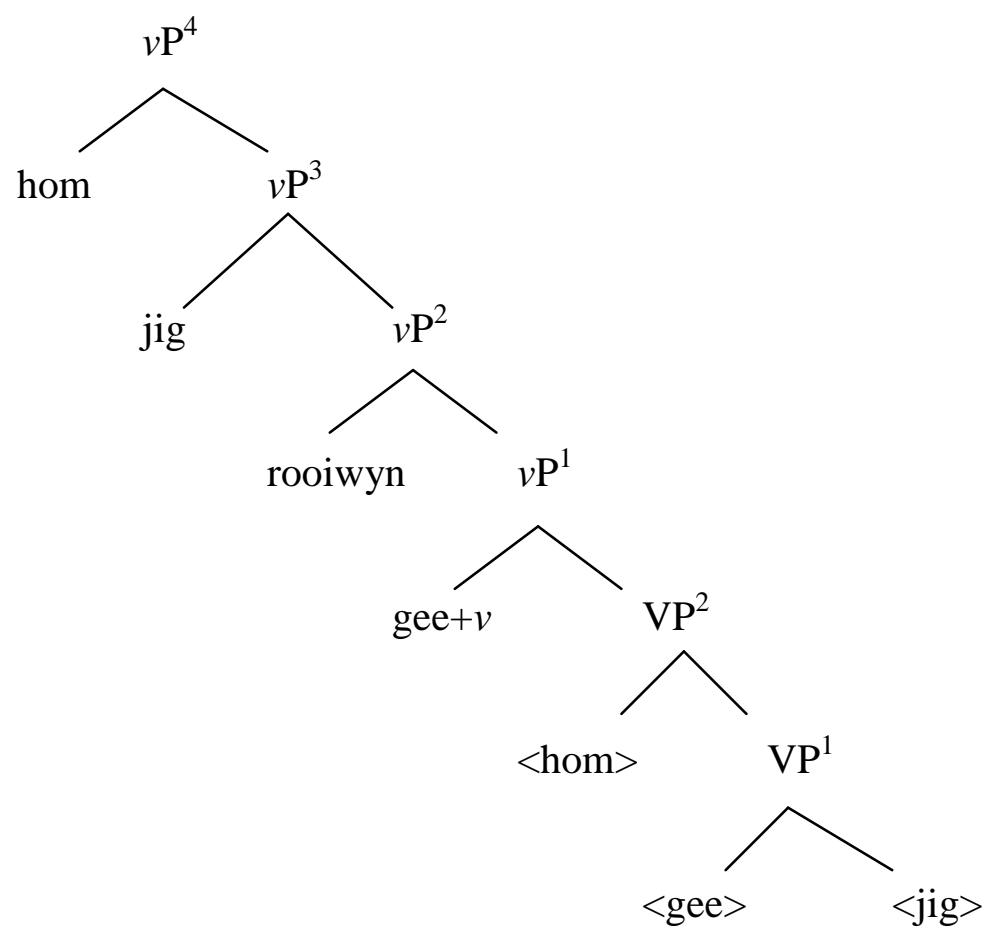


Die laaste drie stappe van die afleiding hou in, eerstens, dat die T saamgevoeg word met $v \mathrm{P}^{4}$ om $\mathrm{TP}^{1}$ te vorm; tweedens, dat die komplekse-v gee met die $\mathrm{T}$ saamgevoeg word; en derdens, dat die subjek DP rooiwyn na die spesifiseerder van die $\mathrm{T}$ verskuif word om $\mathrm{TP}^{2}$ te vorm. Die resultaat word weergegee in (12).

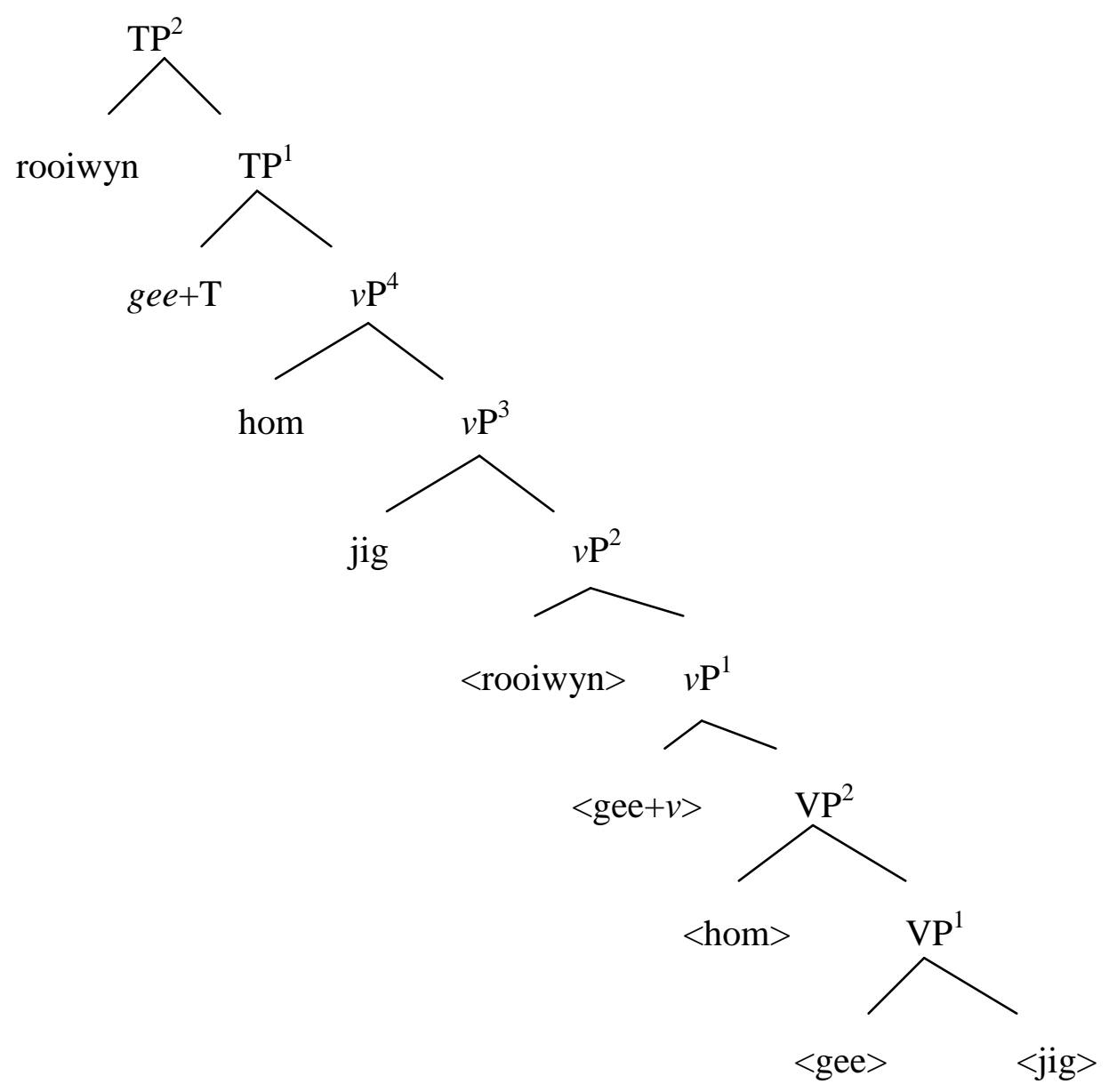

Beskou derdens die afleiding van 'n onakkusatiewe konstruksie, soos geïllustreer deur die volgende $\sin ^{21}$

(13) Water kook (teen $100 \mathrm{C}^{\mathrm{o}}$ ).

By onakkusatiewe konstruksies word aangeneem dat geen $v$ teenwoordig is nie, ${ }^{22}$ die skikking $\operatorname{vir}(13)$ word weergegee in (14):

(14) $\mathrm{N}=\left\{\mathrm{Water}_{1} ; \operatorname{kook}_{1} ; \mathrm{T}_{\text {presens } 1}\right\}$ 
Die afleiding van (13) verloop stapsgewys soos volg:

i. $\quad$ ES van die V kook en die DP water lewer 'n VP;

ii. $\quad$ ES van die T en die VP lewer $\mathrm{TP}^{1}$;

iii. IS van die V kook en die T;

iv. IS van die DP water in die spesifiseerderposisie van die $\mathrm{T}$ lewer $\mathrm{TP}^{2}$.

Die Tema $\theta$-rol word toegeken aan die argument DP as dit met die V saamgevoeg word. Stappe (i-iv) word geïllustreer in (15).

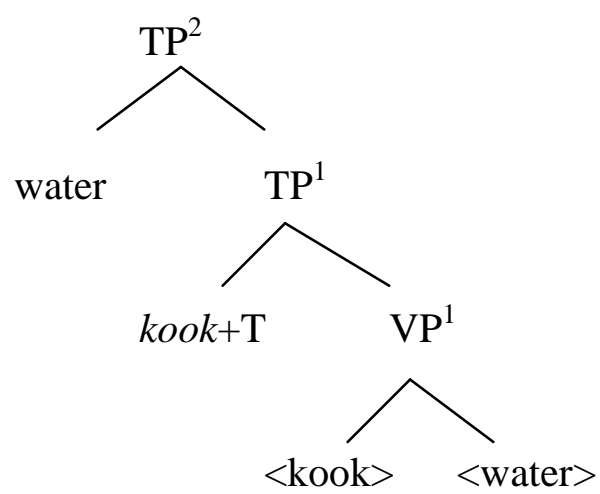

Beskou laastens die afleiding van 'n onergatiewe konstruksie soos geïllustreer deur die sin in $(16)^{23}$; die skikking van dié sin word weergegee in (17).

(16) Karen huil.

(17) $\mathrm{N}=\left\{\right.$ Karen $_{1} ; v_{\text {ervaarder } 1} ;$ huil $\left._{1} ; \mathrm{T}_{\text {presens } 1_{1}}\right\}$

Die afleiding van (16) verloop stapsgewys soos volg:

i. $\quad$ ES van die $\mathrm{V}$ huil en die $v$ lewer $v \mathrm{P}^{1}$;

ii. $\quad$ IS van die die $\mathrm{V}$ huil en die $v$ lewer die komplekse $v$-predikaat;

iii. ES van die DP Karen in die spesifiseerderposisie van die $v$ lewer $v \mathrm{P}^{2}$;

iv. $\quad \mathrm{ES}$ van die $\mathrm{T}$ met $v \mathrm{P}^{2}$ lewer $\mathrm{TP}^{1}$;

v. IS van die komplekse $v$-predikaat huil met die T; 
vi. IS van die DP Karen in die spesifiseerderposisie van die T lewer TP2.

Die DP Karen ontvang die Ervaarder ("Experiencer") $\theta$-rol wanneer dit saamgevoeg word met $\nu \mathrm{P}^{1}$ deur ES; die resultaat van stappe (i-vi) word geïllustreer in diagram (18).

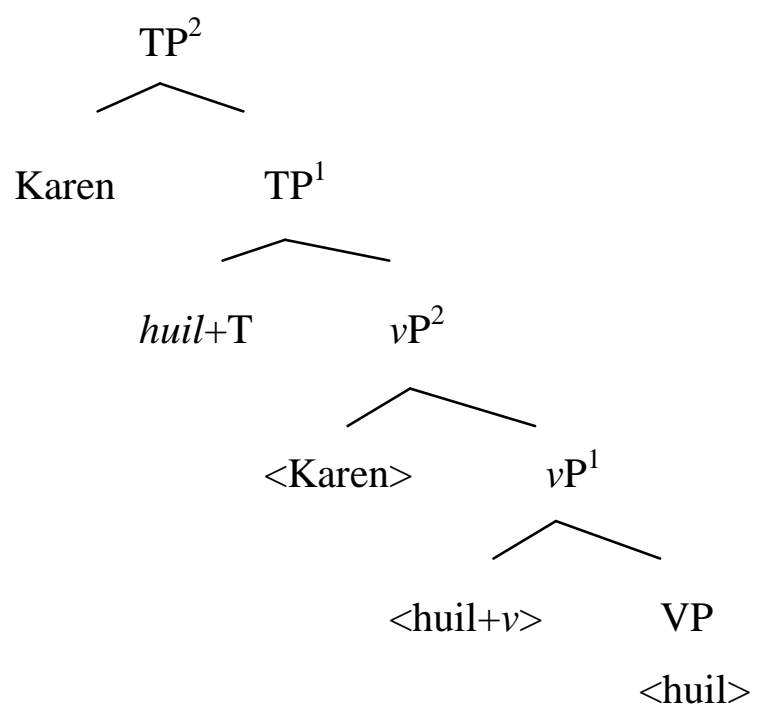

Die afleidings van die vier tipes konstruksies hierbo kan die indruk skep dat sintaktiese bewerkings binne MS meer kompleks en "slordiger" is in vergelyking met ooreenstemmende afleidings in vroeëre modelle binne die P\&P-raamwerk, byvoorbeeld in GB-teorie. Binne MS vind daar duidelik meer bewerkings plaas, en word daar gebruik gemaak van meer funksionele kategorieë. Rizzi (2004:8) maak die volgende opmerking in hierdie verband: "Local simplicity is preserved by natural languages at the price of accepting a higher global complexity, through the proliferation of structural units." In MS vind daar inderdaad meer bewerkings plaas in ' $\mathrm{n}$ gegewe afleiding, maar dit is dieselfde bewerking wat siklies plaasvind, geen konstruksie-spesifieke bewerkings (soos byvoorbeeld NP-Skuif, V-Skuif, ens.) word benodig nie; die sisteem as geheel bly dus steeds optimaal eenvoudig.

\section{Die interne struktuur van $\mathbf{C P}$}

\subsection{Inleiding}

Die kategorie komplementeerder ("complementiser", C) is die hoof van CP, en funksioneer tradisioneel as die inleier van 'n sin. In boomdiagramterme is die CP dus die hoogste projeksie in sinstruktuur. In hoofsinne word die C-posisie gewoonlik nie foneties gerealiseer nie. In 
bysinne, daarenteen, kan die C wel overt gerealiseer word - in Afrikaans byvoorbeeld deur dat en of, soos geïllustreer in (19).
(19) a. Ek vermoed dat hy stadig skryf.
b. Ek wonder of sy sal deelneem.

Binne GB-teorie is die struktuur van die $\mathrm{CP}$ onderhewig aan die stipulasies van X-balkteorie ("X-bar Theory"). ${ }^{24}$ Dit hou in dat die CP bestaan uit 'n hoof C, 'n verpligte IP-komplement ${ }^{25}$ en 'n opsionele spesifiseerder, soos voorgestel in (20).

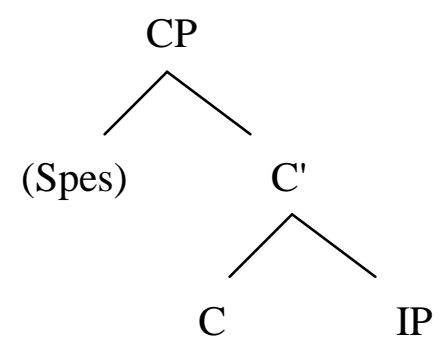

Die spesifiseerderposisie in (20) dien as die landingsplek vir enige vooropgestelde elemente, onder meer verskuifde wh-frases en gefokaliseerde frases. ${ }^{26}$ Radford (1989:530) stel dit dat "Topicalisation, like WH-movement, involves movement of phrases into the C-specifier position." Verder dien die $\mathrm{C}$ as 'n kategorie waaraan vooropgestelde V-elemente (hoofwerkwoorde en hulpwerkwoorde) geadjungeer kan word, 'n proses bekend as I-na-C ("I-to-C", of "Inversion"). 'n Algemene aanname is dat I-na-C plaasvind om 'n "finietheid-kenmerk" ("finiteness feature") in die $\mathrm{C}$ af te merk. ${ }^{27}$

Beskou nou teen hierdie agtergrond die afleiding van vraagkonstruksies en fokuskonstruksies. Eerstens, binne GB-teorie word 'n vraagsin soos dié in (21) afgelei deur die toepassing van minstens drie reëls, naamlik V-na-I, I-na-C en Wh-Skuif. ${ }^{28}$ Die struktuur wat opgelewer word deur dié reëls word vereenvoudig weergegee in (22). ${ }^{29}$

(21) Wat lees hy? 
(22)

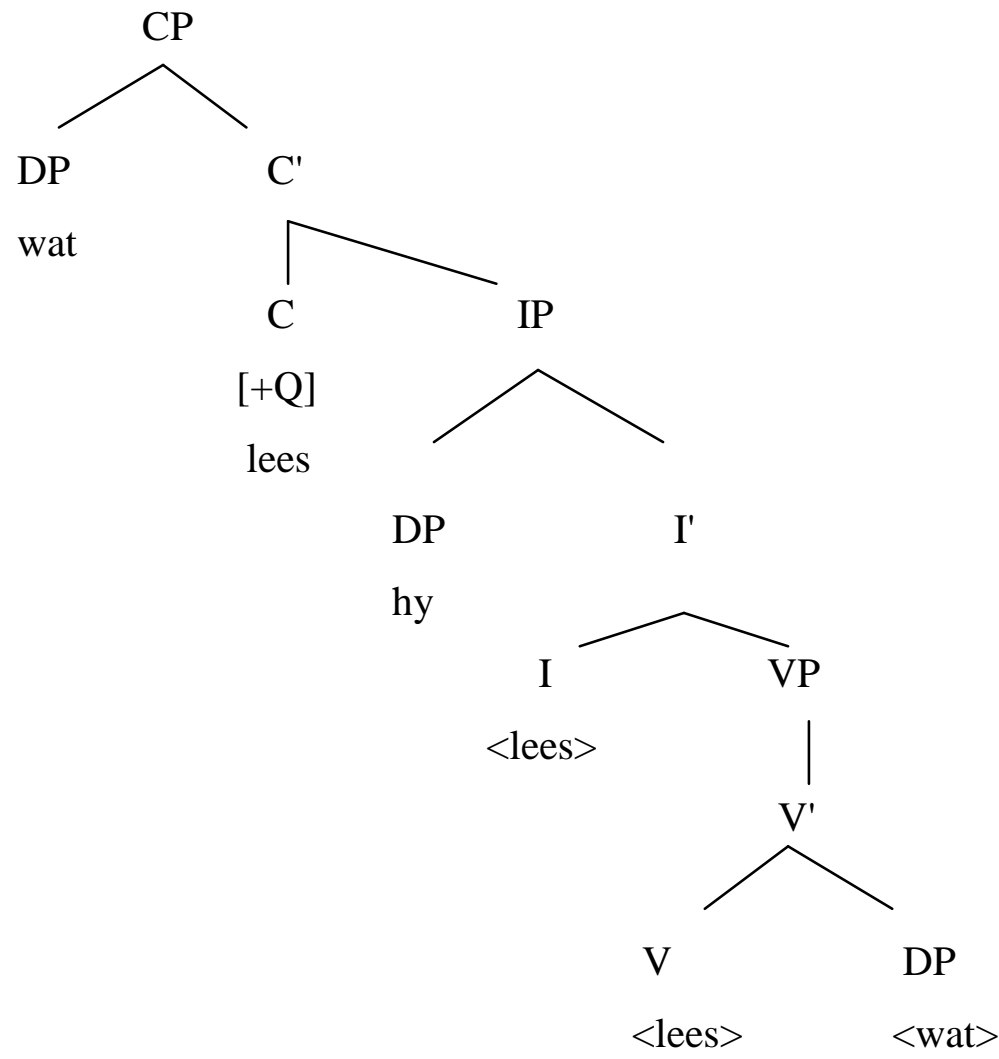

Die C in (22) besit die kenmerk [+Q]. Die feit dat die C 'n Q-kenmerk het, impliseer dat die CP die sinstipe spesifiseer, naamlik of dit 'n vraagsin ([+Q]) of 'n stelsin ([-Q]) is. Op dié manier dra die CP dus daartoe by om die sin pragmaties te kontekstualiseer.

Beskou tweedens die afleiding van fokuskonstruksies, soos geïllustreer deur die voorbeeldsin in (23). Soos in die geval van vraagsinne, word sinne met 'n gefokaliseerde frase ook afgelei deur drie skuifreëls, naamlik V-na-I, I-na-C en Fokalisering (laasgenoemde algemeen bekend as "Topikalisering" in GB-teorie). Die effek van hierdie reëls word weergegee in (24).

(23) Sintaksis ken hy goed. 
(24)

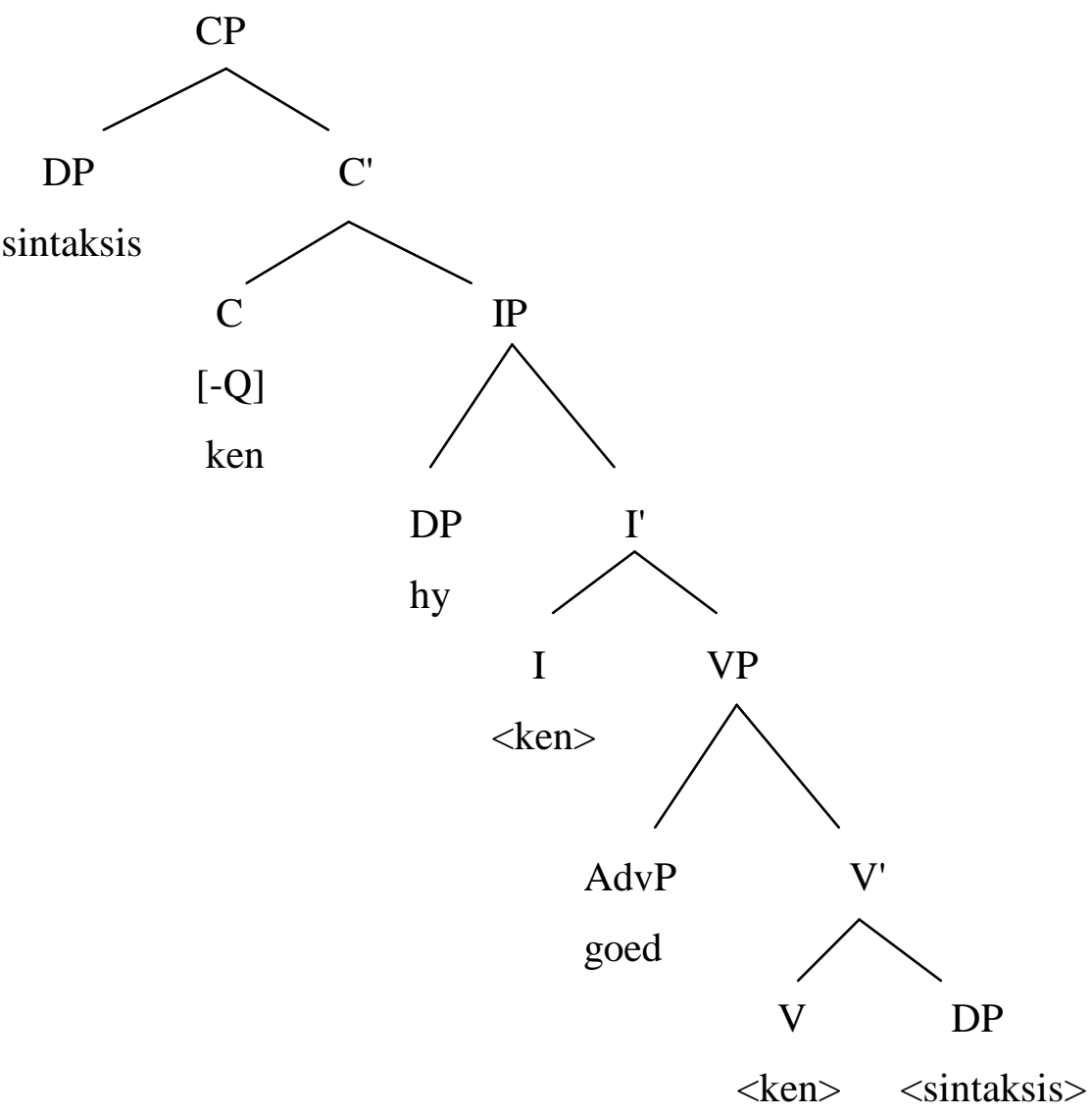

Die funksie van fokalisering is om die hoorder se aandag te vestig op "nuwe inligting" wat in die gespreksituasie aangebied word, dit wil sê, inligting wat nie beskikbaar was in die voorafgaande diskoers nie. Hieruit volg dit dat CP in 'n tweede opsig daartoe bydra om die sin - of meer presies, 'n onderdeel van die sin - pragmaties te kontekstualiseer.

Benewens wh-frases en gefokaliseerde frases, maak GB-teorie voorsiening vir 'n derde soort element wat in die spesifiseerderposisie van die C kan voorkom, naamlik 'n linksgedislokeerde ("left-dislocated") frase. 'n Voorbeeld van so 'n links-dislokasie-konstruksie is die volgende:

(25) Daardie man, ek ken hom goed.

Die funksie van links-dislokasie (LD) is nie om die hoorder se aandag te vestig op nuwe inligting nie, maar eerder om die (reeds bekende) onderwerp van die daaropvolgende mededeling voorop in die hoorder se gedagtes te kry - dit waaroor die res van die sin handel. ${ }^{30}$ In (25) is die frase daardie man byvoorbeeld die onderwerp van die daaropvolgende 
sin, met ander woorde, die entiteit waaroor iets meegedeel word. 'n Kenmerkende eienskap van $\mathrm{LD}$ is die verpligte teenwoordigheid van 'n resumptiewe voornaamwoord ("resumptive pronoun"), hom in die geval van (25). ${ }^{31}$ Sonder 'n resumptiewe voornaamwoord is die sin ongrammatikaal, soos geïllustreer in (26a). In Afrikaans het LD die verdere eienskap dat dit, anders as by wh-vraagvorming en fokalisering, nie 'n verandering meebring in die lineêre volgorde van die strukturele subjek en die finiete werkwoord nie (subjek-werkwoordinversie). In (25) volg die finiete werkwoord byvoorbeeld ná die strukturele subjek $e k$. Die omgekeerde volgorde lei tot ongrammatikaliteit soos geïllustreer in (26b).

\footnotetext{
a. *Daardie man, ek ken goed.

b. *Daardie man, ken ek hom goed.
}

Binne GB-teorie is algemeen aanvaar dat 'n links-gedislokeerde frase basis-gegenereer word in die spesifiseerderposisie van die C. Met ander woorde, anders as in die geval van whkonstruksies en fokuskonstruksies, vind daar nie verskuiwing plaas in die afleiding van LDkonstruksies nie. Soos by die eersgenoemde twee tipes konstruksies, het die CP in die geval van LD-konstruksies egter ook 'n pragmatiese funksie: hier speel dit 'n rol in die kontekstualisering van die onderwerp van die mededeling.

Kortom, selfs binne die GB-raamwerk is dit duidelik dat die CP se funksie verder strek as blote inleier van 'n sin: dit dien ook as 'n koppelvlak tussen die diskoersverwante konteks en die sinsverwante aspekte van sintaksis. Rizzi (1997:283) stel dit soos volg: "As such, we expect the $\mathrm{C}$ system to express at least two kinds of information, one facing the outside [= diskoers-relevant $]$ and the other facing the inside [= sintakties-relevant]."

\subsection{Besware teen die GB-analise van CP}

Die GB-analise van die CP soos hierbo uiteengesit is wyd gebruik in die beskrywing van whkonstruksies en Fokuskonstruksies in 'n verskeidenheid tale. Dit het egter mettertyd duidelik geword dat dié analise onvoldoende is op sowel empiriese as konseptuele gronde. Hieronder volg ' $n$ kort bespreking van enkele van die hoofbesware teen die GB-analise van die CP.

'n Eerste probleem betref die X-balkstipulasie dat elke maksimale projeksie XP een en slegs een spesifiseerderposisie mag hê. Dit is egter moontlik dat daar meer as een frase op die 
linkergrens van 'n sin mag voorkom. Beskou byvoorbeeld die sinne in (27). (27a) bevat sowel 'n links-gedislokeerde frase (daardie man) as 'n gefokaliseerde frase (hom); (27b) bevat 'n links-gedislokeerde frase (dié man) sowel as 'n wh-frase (wanneer); en (27c) bevat twee linksgedislokeerde frases (my pa en sy siekte).

(27) a. Daardie man, hom ken ek goed.

b. Dié man, wanneer gaan hy kom?

c. My pa, sy siekte, hy kan dit maar net nie aanvaar nie. (Oosthuizen 1994:169)

Die probleem is nie beperk tot die spesifiseerderposisie van die C nie. Die X-balkstipulasie dat 'n CP slegs een hoof $\mathrm{C}$ mag hê is ook problematies in die lig van sinne soos die Nederlandse voorbeeld in (28a) en die Afrikaanse voorbeeld in (28b). In beide gevalle is daar nie net een nie, maar twee overte komplementeerders ( $o f$ en dat), wat dui op twee Choofposisies.

(28) a. Wie dink je of dat de meisjes gezien hebben? (Hoekstra \& Zwart 1994:194)

b. Ek twyfel of dat hulle sal kom.

(Oosthuizen 1994:165)

'n Verwante probleem betref die algemene aanname, in sowel GB-teorie as MS, dat adjunksie van 'n finiete $\mathrm{V}$ altyd aan die linkergrens van 'n C-hoof plaasvind. In (29), egter, verskyn die vooropgestelde finiete werkwoord het regs van die C-hoof dat, wat suggereer dat die $\mathrm{V}$ nie aan die dat-C geadjungeer is nie, maar aan 'n ander, afsonderlike hoofkategorie.

(29) My gevoel is dat het dit maar net so gebeur.

(Oosthuizen 1994:167)

Voorbeelde soos dié in (27)-(29) is om verskeie redes problematies vir die GB-analise van die CP. Aan die een kant kan 'n enkele generiese spesifiseerderposisie onder die CP as 'n landingsplek vir verskuifde frases, of as 'n basisposisie vir LD-frases, nie die onderskeiding uitdruk tussen die diverse elemente wat daarin mag voorkom nie. Op semanties-pragmatiese gronde is daar immers 'n duidelike verskil tussen wh-frases, gefokaliseerde frases en LDfrases. Aan die ander kant kan 'n enkele C-posisie nie die feite in (28) en (29) verklaar nie. Teen hierdie agtergrond argumenteer Hoekstra \& Zwart vir 'n gedifferensieerde CP-struktuur, spesifiek 'n struktuur met twee funksionele hoofde: "Hieruit leiden we af dat CP twee 
spesifiseerders bevat, en dus ook twee hoofden." (1994:192); "In overeenstemming met de Xbar theorie kunnen we beide hoofden een eigen projectie geven: WhP en TopP." (1994:195) Hoekstra \& Zwart se voorstel is dus dat die C in twee afsonderlike hoofde verdeel word, naamlik (i) 'n Wh-hoof, wie se spesifiseerderposisie beskikbaar is vir verskuifde wh-frases, en (ii) 'n Top(iek)-hoof, wie se spesifiseerderposisie beskikbaar is vir gefokaliseerde frases. CP word dus heranaliseer as twee frases, naamlik TopP en WhP, soos in (30). ${ }^{32}$

$[\mathrm{WhP}[\mathrm{TopP} \ldots[\mathrm{IP} \ldots]]]$

Hoekstra \& Zwart (1994) se voorstel het verskeie voordele. Eerstens maak dit voorsiening vir twee spesifiseerderposisies, dit wil sê, dit bied twee potensiële landingsplekke vir verskuifde frases (anders as die GB-analise wat net een spesifiseerderposisie bied). Tweedens kan die analise in (30) die komplementeerder-feite in sinne soos (28) en (29) verklaar deurdat dit voorsiening makk vir twee C-hoofde. Tog kan Hoekstra \& Zwart se analise steeds nie die verskil tussen fokalisering en LD verklaar nie; trouens, in hulle analise word LD-konstruksies glad nie in berekening gebring nie. ' $n$ Verdere potensiële probleem betref sinne wat meer as twee vooropgestelde frases bevat. Byvoorbeeld, sowel die Italiaanse sin in (31a) as die Afrikaanse sin in (31b) bevat drie vooropgestelde frases; die analise in (30) maak egter net voorsiening vir twee spesifiseerderposisies as landingsplekke vir sulke frases.

(31) a. A Gianni, Questo, domani, gli dovrete dire.

'To Gianni, this, tomorrow, you should tell him.'

(Rizzi 1997:291)

b. Jan, op die stoep, daar het ek hom gesien.

Oosthuizen (1994) argumenteer, op basis van konstruksies soos dié in (27), dat C nog 'n CP as komplement mag neem om so 'n dubbele CP-struktuur te lewer, soos in (32). Let op dat Oosthuizen se analise nie tussen verskillende hoofde, soos byvoorbeeld Hoekstra \& Zwart (1994) se Wh en Top, onderskei nie.

\section{$[\mathrm{CP}[\mathrm{CP}[\mathrm{IP} \ldots]]]$}

Die probleme met Hoekstra \& Zwart (1994) se analise wat hierbo uitgewys is, geld ook vir die analise in (32). Dit kan nie konstruksies beskryf wat meer as twee vooropgestelde frases 
bevat nie, en dit maak ook nie voorsiening vir die semanties-pragmaties uiteenlopende aard van sulke frases nie.

In die volgende afdeling word in meer besonderhede aandag gegee aan 'n derde voorstel in verband met ' $n$ gedifferensieerde CP, naamlik die invloedryke analise van Rizzi (1997).

\subsection{Rizzi se analise van Topiek en Fokus}

Rizzi (1997) verdeel die enkele C-hoof in vier funksionele hoofde, elk met sy eie projeksie: Topiek ("Topic"), Fokus ("Focus"), Krag ("Force"), en Finietheid ("Finiteness"). Struktureel kan die onderlinge samehang tussen dié hoofde soos volg voorgestel word (waar die asterisk* dui op rekursiwiteit):

$$
[\text { ForP }[\text { TopP* }[\text { FocP }[\text { TopP* }[\text { FinP }[\text { IP ... }]]]]]]^{33}
$$

(Rizzi 1997:297)

In hierdie afdeling word aandag gegee aan die funksionele projeksies Topiekfrase ("Topic Phrase", TopP) en Fokusfrase ("Focus Phrase", FocP). Die diskoers-semantiese verskil tussen Topiek en Fokus is in afdeling 3.2 uitgewys en word verder geïllustreer in (34); Rizzi (1997:285) gebruik dié sinspaar om elemente wat binne CP voorkom pragmaties te kategoriseer.

(34) a. Your book, you should give t to Paul (not to Bill).

b. YOUR BOOK, you should give $t$ to Paul (not mine). ${ }^{34}$

(34a) is volgens Rizzi 'n voorbeeld van Topikalisering ${ }^{35}$ aangesien die vooropgestelde frase your book informasie aanbied wat reeds bekend is binne die voorafgaande diskoers. 'n Topiek word gevolg deur die Kommentaar ("Comment") wat nuwe informasie aanbied; 'n Topiek se doel is dus om dit wat daarop volg binne 'n gegewe diskoerskonteks te plaas. Gundel \& Fretheim (2004:181) stel dit dat "Topics are relationally given, by definition, in the sense that they are what the sentence/utterance is about. They provide the context for the main predication, which is assessed relative to the topic."

(34b), daarenteen, is 'n voorbeeld van wat Rizzi (1997:285) Fokalisering noem: "Here the preposed element, bearing focal stress, introduces new information, whereas the open 
sentence expresses contextually given information, knowledge that the speaker presupposes to be shared with the hearer." Fokus en Topiek is dus in diskoers-semantiese terme teenoorgesteldes deurdat hulle onderskeidelik "nuwe" en "bekende" informasie verteenwoordig. Die balans tussen ou en nuwe informasie is belangrik in talige kommunikasie: "te veel" nuwe informasie kan 'n uiting/gesprek onverstaanbaar of moeilik verstaanbaar maak, terwyl "te veel" bekende informasie die oogmerk van informatiewe kommunikasie teenwerk. ${ }^{36}$

Buiten diskoers-semantiese gronde moet daar ook formele sintaktiese gronde wees om die funksionele kategorieë Topiek en Fokus van mekaar te onderskei; elkeen het immers 'n unieke posisie binne die uitgebreide CP. Hieronder word vier sintaktiese verskille tussen Topiek en Fokus soos deur Rizzi geïdentifiseer, kortliks beskryf.

\subsubsection{Resumptiewe voornaamwoorde}

Volgens Rizzi (1997:289) word getopikaliseerde frases, maar nie gefokaliseerde frases nie, met 'n resumptiewe voornaamwoord geassosieer: "A topic can involve a resumptive clitic within the comment ... on the other hand a focalised constituent is inconsistent with a resumptive clitic." ${ }^{37}$ Die teenwoordigheid van so 'n voornaamwoord sluit dus die moontlikheid uit dat 'n vooropgestelde frase gefokaliseerd is. Die omgekeerde geld klaarblyklik nie noodwendig nie; Rizzi se sin in (34a) bevat byvoorbeeld ' $n$ TopP sonder ' $n$ resumptiewe voornaamwoord. In Afrikaans, egter, moet ' $n$ TopP verplig geassosieer wees met 'n resumptiewe voornaamwoord in die Kommentaar, soos blyk uit die verskil in grammatikaliteit tussen (35a,b). 'n FocP, daarteenoor, is nie versoenbaar met 'n resumptiewe voornaamwoord nie, soos die verskil in grammatikaliteit tussen $(35 \mathrm{c}, \mathrm{d})$ aantoon.

(35) a. Witwyn, ek kan dit nie drink nie.

b. *Witwyn, ek kan nie drink nie.

c. Witwyn kan ek nie drink nie.

d. *Witwyn kan ek dit nie drink nie.

Soos blyk uit die sinne in (35a) en (35c), bring Topikalisering in Afrikaans nie ' $n$ verandering in woordorde te weeg nie; meer spesifiek, die lineêre volgorde van die subjek $e k$ en die finiete werkwoord kan bly onveranderd. In die geval van Fokalisering, egter, moet inversie van die 
subjek en die finiete werkwoord verplig plaasvind. ${ }^{38}$ Kontrasteer in hierdie opsig die grammatikale sinne in $(35 a, c)$ met die ongrammatikale voorbeelde in $(36 a, b)$ onderskeidelik.

(36) a. *Witwyn, kan ek dit nie drink nie.

b. *Witwyn ek kan nie drink nie.

Soos reeds in afdeling 3.1 genoem, word inversie van die subjek en die finiete werkwoord binne GB-teorie meegebring deur $\mathrm{T}(=\mathrm{I})$-na-C: die aanname is dat die $\mathrm{C}$ ' $\mathrm{n}$ sterk finietheidkenmerk het wat deur die T afgemerk word. Die feit dat Fokalisering in Afrikaans verplig inversie meebring, impliseer dus dat die seleksie van 'n Fokus-hoof gepaard gaan met die seleksie van 'n hoof met 'n sterk finietheid-kenmerk, dit wil sê, die Fin-hoof binne Rizzi se struktuur in (33). Dus sal 'n Fokus-hoof altyd (direk) gevolg word deur 'n element wat finietheid uitdruk; vir huidige doeleindes word aangeneem dat so 'n element, ten minste in hoofsinne, ' $\mathrm{n}$ finiete $\mathrm{V}$ is wat deur T-na-Fin vooropgestel is. Teen hierdie agtergrond kan die analise van 'n fokuskonstruksie soos die een in (35c) vereenvoudig voorgestel word soos in (37) hieronder. ${ }^{39}$

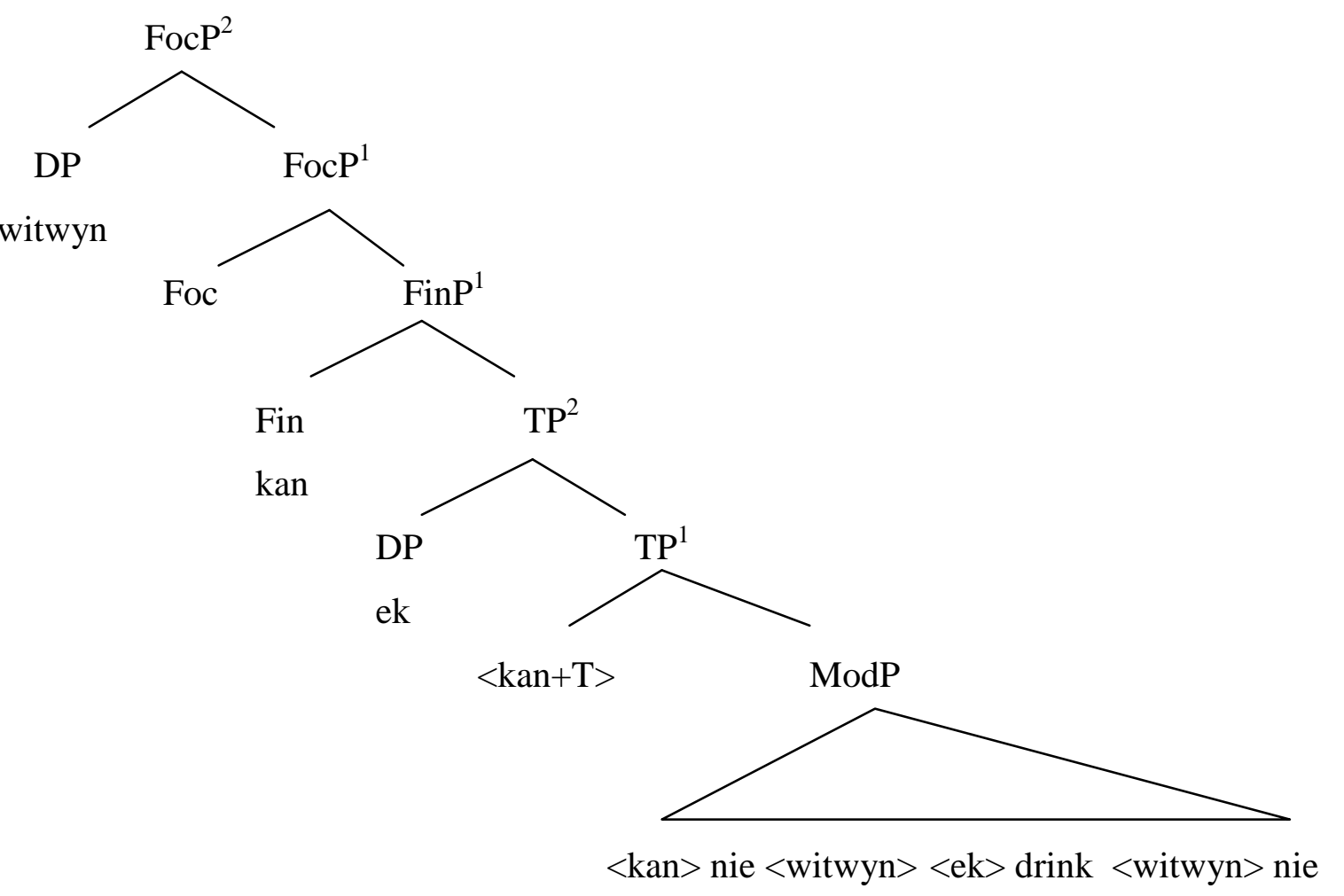


'n Analise soos die een hierbo bring egter 'n probleem na vore in verband met die tweede TopP wat tussen FocP en FinP voorkom in Rizzi se struktuur in (33). Indien aanvaar word, in navolging van Beninca' \& Poletto (2004:57), dat "There is no Topic projection lower than Focus", kan 'n meer akkurate voorspelling gemaak word oor die strukturele posisie en relatiewe volgorde van Topiek en Fokus binne die CP-domein. Beskou byvoorbeeld die sinne in $(38)$.

(38) a. Jan, witwyn, hy kan dit nie drink nie.

b. Jan, witwyn, kan hy nie drink nie.

c. *Jan, witwyn, dit kan nie drink nie.

(38a) bevat twee getopikaliseerde frases (Jan, witwyn), terwyl (38b) 'n getopikaliseerde frase (Jan) gevolg deur 'n gefokaliseerde frase (witwyn) bevat; albei sinne is grammatikaal. Sin (38c) is egter ongrammatikaal; in hierdie geval word die gefokaliseerde frase (Jan) gevolg deur 'n getopikaliseerde frase (witwyn). Die ongrammatikaliteit van (38c) kan verklaar word in terme van die wysiging van Rizzi se struktuur in (33) wat voorgestel word deur Beninca' \& Poletto (2004). Die gewysigde struktuur, weergegee in (39), behels die weglating van die laagste TopP; hiervolgens kan 'n getopikaliseerde frase nie volg op 'n gefokaliseerde frase in die CP-domein nie.

\section{$[$ TopP $[$ FocP $[$ FinP ...]]]}

Verder kan Rizzi se bewering dat 'n resumptiewe element nie versoenbaar is met 'n gefokaliseerde frase nie, teen die agtergrond van sinne soos die een in (35b) meer spesifiek gemaak word deur die volgende taalspesifieke beperking: as daar 'n Top-hoof teenwoordig is in die CP-domein in Afrikaans, moet daar verplig 'n geassosieerde resumptiewe element wees in die Kommentaar.

\subsubsection{Voorkoms van Topiek en Fokus saam met wh-frases}

Rizzi (1997:291) stel dit dat "A Wh operator in main questions is compatible with a Topic in a fixed order (Top Wh), whereas it is incompatible with a Focus." Met ander woorde, volgens Rizzi kan 'n getopikaliseerde frase en 'n vooropgestelde wh-frase saam in hierdie volgorde voorkom, maar nie 'n gefokaliseerde frase en 'n wh-frase nie. Die sinne in (40a-d) illustreer 
hierdie beperking op die distribusie van TopP, FocP en wh-frases. (Geriefshalwe word die getopikaliseerde frases en hulle geassosieerde resumptiewe voornaamwoorde in (40) met dieselfde subskrif gemerk.)

(40) a. Daardie $\operatorname{man}_{\mathrm{i}}$, watter vrou het $\mathrm{hy}_{\mathrm{i}}$ vermoor?

b. *Watter vrou, daardie $m_{i}$, het hy $y_{i}$ vermoor?

c. *Daardie $\operatorname{man}_{\mathrm{i}}$, watter vrou hy $\mathrm{y}_{\mathrm{i}}$ het vermoor?

d. $\quad *$ Daardie $\operatorname{man}_{\mathrm{i}}$, watter vrou $\mathrm{j}_{\mathrm{j}}$ het $\mathrm{hy}_{\mathrm{i}}$ wie $_{\mathrm{j}}$ vermoor?

Rizzi (1997:299) se voorstel is dat "The question operator ends up in Spec of Foc in main questions", wat ondersteun word deur die kontras tussen (40a) en (40c). Hieruit kan afgelei word dat as subjek-inversie nie plaasvind nie, soos in (40c), dit lei tot 'n ongrammatikale sin; dus moes fokalisering van die wh-frase plaasgevind het, soos in (40a). Sin (40d) illustreer dat 'n vooropgestelde wh-frase onversoenbaar is met 'n resumptiewe voornaamwoord, 'n verdere aanduiding dat dit gefokaliseer is. Op grond van die feite in (40) kan die relatiewe volgorde van getopikaliseerde frases en gefokaliseerde wh-frases in Afrikaans dus soos volg voorgestel word binne die raamwerk van Rizzi se struktuur in (33). Let op dat daar in terme van (41) geen Top-hoof ná 'n wh-frase kan voorkom nie.

$$
\text { [TopP [Top [ FocP Wh-O [ Foc ...]]]] }
$$

Die voorstel van Rizzi (1997:291) dat 'n gefokaliseerde frase en 'n verskuifde wh-frase nie saam kan voorkom nie, sluit die moontlikheid uit dat daar 'n FocP aan die linkerkant van 'n verskuifde wh-frase mag wees: die wh-frase vul immers reeds die spesifiseerderposisie van die enkele Foc-hoof wat beskikbaar is in die CP-domein. Die konstruksie in (42) is egter ' $n$ teenvoorbeeld vir die struktuur in (41), wat gebaseer is op Rizzi se voorstel.

(42) Die $\operatorname{man}_{\mathrm{i}}$, gister $\mathrm{j}$, watter vrou het $\mathrm{hy}_{\mathrm{i}}\left(\right.$ toe $\left._{\mathrm{j}}\right)$ vermoor?

Die opsionaliteit van die resumptief toe dui aan dat die vooropgestelde frase gister beide getopikaliseer of gefokaliseer kan wees. Indien aangeneem word dat gister gefokaliseer is, is (42) duidelik onversoenbaar met die struktuur in (41). Beninca' \& Poletto (2004:57) bied 'n meer gedifferensieerde analise van die CP-domein as dié in (33) en (41): "We claim that 
Focus can also host more than one element, each with a peculiar function ... Hence, FocP is not a single XP but a 'field' ". Beninca' \& Poletto se voorstel word bespreek in afdeling 3.4.

Rizzi se beperking op die gelyktydige voorkoms van 'n wh-frase en 'n gefokaliseerde frase in die CP-domein stem ooreen met 'n waarneming van Hoekstra \& Zwart (1994). In afdeling 3.2 is gemeld dat Hoekstra \& Zwart die C verdeel in twee funksionele hoofde, naamlik 'n Whhoof en 'n "Topiek"-hoof (die ekwivalent van wat in die meer onlangse literatuur bekend staan as 'n Fokus-hoof; kyk voetnoot 26), in hierdie volgorde. In dié opsig maak Hoekstra \& Swart (1994:203) die volgende opmerking: "Het probleem is dat de Spec,TopP en de Spec,WhP schijnbaar nooit gelijktijdig gevuld kunnen zijn." Hulle gee die voorbeelde in $(43 a, b)$ ter illustrasie:

(43) a. *Wanneer mijn notities heeft Jan gelezen?

b. *Wanneer heeft mijn notities Jan gelezen?

Die kwalifikasie "schijnbaar" is belangrik hier. Hoekstra \& Zwart (1994:204) meld naamlik dat wh-frases en "getopikaliseerde" (d.w.s. gefokaliseerde) frases wel saam moet kan voorkom in die CP-domein, ten minste in daardie gevalle waar die "getopikaliseerde" frase vanuit ' $n$ bysin verskuif na die linkergrens van 'n hoofsin. Hulle illustreer die afleiding van so 'n konstruksie met die volgende voorbeeld: ${ }^{40}$

(44) a. Morgen weet ik hoe laat ik kan.

b. [TopP Morgen $_{i}$ weet $[\mathrm{AgSP} i \mathrm{ik} \ldots \text { [WhP [hoe laat }]_{\mathrm{j}}\left[\right.$ TopP $\mathrm{t}_{\mathrm{i}}\left[\mathrm{AgSP}\right.$ ik $\left.\left.\left.\left.\mathrm{t}_{\mathrm{i}} \mathrm{t}_{\mathrm{j}} \mathrm{kan}\right]\right]\right]\right]$

In 'n standaard-skuifanalise beweeg die "getopikaliseerde" frase morgen eers na die spesifiseerderposisie van die "Top"-hoof in die bysin, en vandaar na die "TopP" van die hoofsin. Die eerste verskuiwing hou egter in dat morgen en die vooropgestelde wh-frase hoe laat saam voorkom in die C-domein van die bysin. ${ }^{41}$ Daar sou dus geargumenteer kon word dat die C-domein voorsiening moet maak vir beide ' $n$ WhP en 'n FocP wat - ten minste in die afleiding van sinne soos die een in (44a) - gelyktydig gevul kan wees. Dit is nie duidelik hoe die afleiding van sulke sinne binne Rizzi se raamwerk beskryf kan word nie. 
Soos blyk uit die voorbeelde in (45) is die Afrikaanse ekwivalente van die Nederlandse sinne in (43) ook ongrammatikaal:

(45) a. *Waar my boek het Jan weggesteek?

b. *Waar het my boek Jan weggesteek?

Oënskynlik is daar dus 'n volgorde-beperking op die distribusie van wh-frases en gefokaliseerde frases. In sinne waar albei voorkom in die CP-domein, moet die wh-frase laer in die struktuur staan as ('n) gefokaliseerde frase(s). So 'n beperking, uitgedruk in (46), sou die verskil in grammatikaliteit tussen die sinne in (45) en die een in (42) kon verklaar.

$$
\text { [TopP }[\text { Top [ FocP Foc ... [ wh-frase ]]]] }
$$

\subsubsection{Ongemodifiseerde kwantifiseerders}

Volgens Rizzi (1997:290) kan ongemodifiseerde kwantifiseerder-uitdrukkings ("bare quantificational elements") gefokaliseer word, maar nie getopikaliseer word nie: "Quantificational elements (no one, all, etc.) which are not associated to a lexical restriction within the DP cannot be topics ... while they easily allow focalization." Hierdie beperking geld klaarblyklik ook vir ongemodifiseerde kwantifiseerders in Afrikaans, soos albei, almal, elkeen, alles, ens. ${ }^{42}$ Beskou byvoorbeeld die volgende sinne:

(47) a. Al die kinders, ek het hulle gesien.

b. *Almal, ek het hulle gesien.

(48) a. Elkeen wat gedruip het, ek wil julle vandag spreek.

b. $\quad *$ Elkeen, ek wil julle vandag spreek.

(49) a. Al die kinders het ek gesien.

b. Almal het ek gesien.

(50) a. Elkeen wat gedruip het wil ek vandag spreek.

b. Elkeen wil ek vandag spreek. 
Soos die verskil in grammatikaliteit tussen die (a) en (b) sinne in (47) en (48) aantoon, kan 'n ongemodifiseerde kwantifiseerder nie getopikaliseer word in Afrikaans nie. Die grammatikaliteit van die sinne in (49) en (50) illustreer dat sowel gemodifiseerde as ongemodifiseerde kwantifiseerders wel gefokaliseer kan word.

Die waarneming in verband met ongemodifiseerde kwantifiseerders verteenwoordig 'n verdere sintaktiese verskil tussen topikalisering en fokalisering, 'n verskil wat formeel uitgedruk kan word deur voorsiening te maak vir Topiek en Fokus as afsonderlike funksionele hoofde binne die CP-domein.

\subsubsection{Swak Oorkruising}

Die verskynsel van Oorkruising ("Cross-over") hou verband met die aanvaarbaarheid al dan nie van koreferensiële verhoudings in gevalle waar 'n nominale kategorie vooropgestel word en in die proses oor sy (gekoïndekseerde) antesedent beweeg. In die literatuur word daar onderskei tussen twee soorte Oorkruising, naamlik Sterk Oorkruising ("Strong Cross-over", SCO) en Swak Oorkruising ("Weak Cross-over", WCO). ${ }^{43}$ SCO kan geïllustreer word met die voorbeeld in (51).

$* \mathrm{Wie}_{\mathrm{i}}$ dink hy $\mathrm{y}_{\mathrm{i}}$ het jy gesien $\mathrm{t}_{\mathrm{i}}$ ?

In die struktuur onderliggend aan (51) word die R-uitdrukking wie gebind deur die voornaamwoord $h y$. In terme van die GB-Bindingsteorie soos uiteengesit in byvoorbeeld Chomsky (1981, 1982), word 'n kategorie X gebind deur 'n kategorie Y indien Y (i) vir X kkommandeer en (ii) met $\mathrm{X}$ gekoïndekseer is. ${ }^{44}$ Die lê van so 'n koreferensiële verhouding is egter ontoelaatbaar in terme van Bindingsbeginsel $\mathrm{C}$, wat lui dat 'n R-uitdrukking soos wie altyd vry moet wees, dit wil sê, nie gebind mag wees deur enige k-kommanderende kategorie nie. ${ }^{45}$ In die afleiding van $\sin (51)$ is wie oor sy antesedent hy verskuif na die linkergrens van die hoofsin. Die ongrammatikaliteit van die sin is egter nie die resultaat van die verskuiwing nie, maar van die oortreding van Bindingsbeginsel C: die R-uitdrukking wie mag nie (ook via sy spoor) in 'n koreferensiële verhouding met die voornaamwoord hy tree nie. Kortom, SCO verwys na 'n oortreding van beginsel $\mathrm{C}$ van die GB-Bindingsteorie. ${ }^{46}$ 
Beskou vervolgens die voorbeeld in (52a) ter illustrasie van Swak Oorkruising; die struktuur van (52a) voor die vooropplasing van wie kan vereenvoudig voorgestel word soos in (52b). ${ }^{47}$

(52) a. * Wie $_{i}$ het $\operatorname{Jan}_{\mathrm{i}}$ se ma lief $t_{\mathrm{i}}$ ?

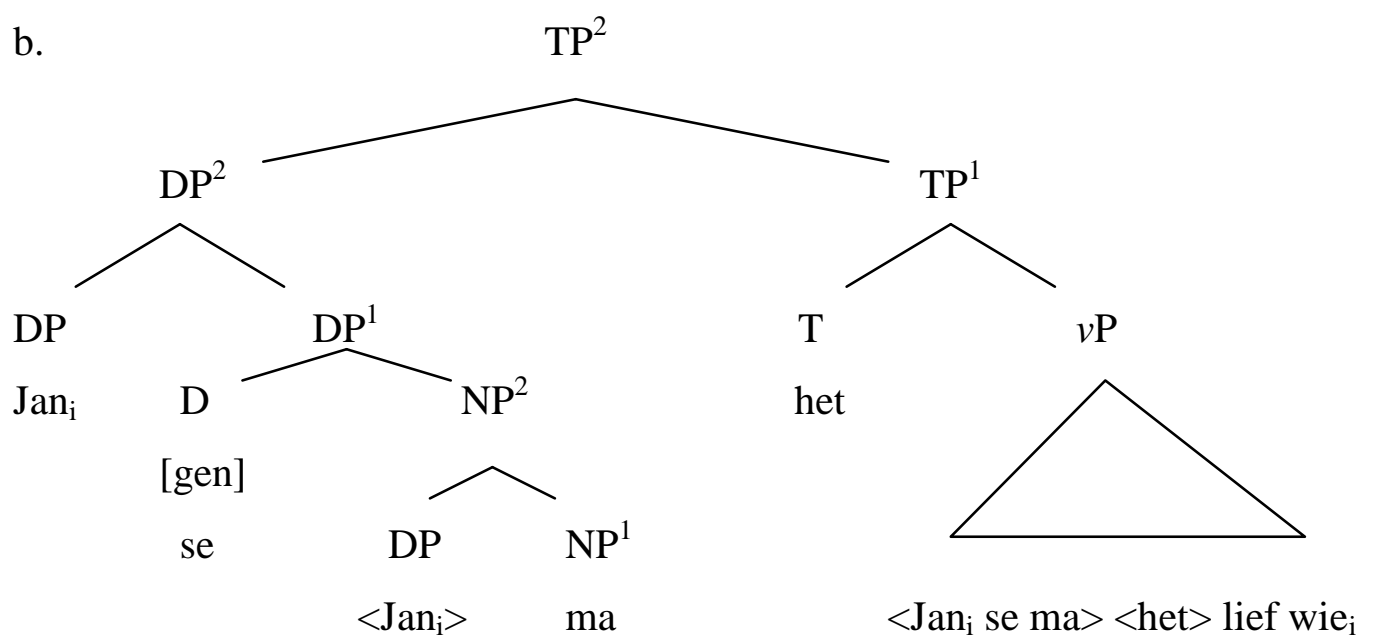

In (52b) vorm die DP Jan deel van die subjek Jan se ma. Let op dat hierdie DP nie die objekDP wie k-kommandeer nie. In die afleiding van (52a) is die R-uitdrukking wie oor sy antesedent Jan verskuif na die linkergrens van die sin; die antesedent k-kommandeer steeds nie die verskuifde R-uitdrukking of sy spoor nie. Die ontoelaatbaarheid van 'n koreferensiële verhouding tussen Jan en wie in (52a) kan dus nie verklaar word as 'n oortreding van Bindingsbeginsel $\mathrm{C}$ nie, wat dit duidelik maak waarom hierdie soort Oorkruising beskryf word as "swak".

Die verklaring van die ongrammatikaliteit van 'n WCO-konstruksie soos in (52a) val buite die bereik van hierdie artikel. WCO-verskynsels is egter interessant vir 'n ondersoek na die fyn struktuur van die CP-domein omdat dit dui op 'n verdere sintaktiese verskil tussen Topiek en Fokus. Soos Rizzi (1997:290) dit stel: "A topic never gives rise to any Weak-cross-over effect. Such effects are detectable with focus". Beninca' \& Poletto (2004:56) stel dié punt soos volg: "Only focalized XPs appear to be related to a variable inside the clause ...Weak crossover can be used as a test to distinguish between Topic and Focus elements". Kortom, slegs gefokaliseerde frases kan in 'n koreferensiële verhouding tree met 'n veranderlike spesifiek, met sy spoor/kopie - binne die sin; getopikaliseerde frases kan nie in so 'n verhouding tree nie. Anders gestel, gefokaliseerde frases toon sensitiwiteit vir WCO-effekte 
terwyl getopikaliseerde frases dit nie doen nie. Dié verskil tussen Topiek en Fokus word geïllustreer deur die verskil in grammatikaliteit tussen (53a,b). Let op dat die teenwoordigheid van die resumptiewe element hom in (53a) ook daarop dui dat dié sin wel 'n voorbeeld van topikalisering is.

a. $\operatorname{Koos}_{\mathrm{i}}, \mathrm{sy}_{\mathrm{i}}$ meisie verneuk hom ho $_{\mathrm{i}}$ (Topikalisering)
b. ${ }^{*} \mathrm{Koos}_{\mathrm{i}}, \mathrm{sy}_{\mathrm{i}}$ meisie verneuk $\mathrm{t}_{\mathrm{i}}$ (Fokalisering)

WCO-verskynsels hang saam met verskuiwing, soos hierbo duidelik gemaak is. Die verskil tussen getopikaliseerde en gefokaliseerde frases ten opsigte van WCO sou dus moontlik verklaar kon word deur aan te neem dat fokalisering, maar nie topikalisering nie, die resultaat is van 'n skuifbewerking. Indien 'n getopikaliseerde frase basis-gegenereer word in die CPdomein, sou mens met ander woorde nie verwag dat dit sensitief is vir WCO-effekte nie.

Die WCO-verskil tussen Topiek en Fokus skakel op 'n interessante manier met die drie sintaktiese verskille wat in afdelings 3.3.1-3.3.3 bespreek is, 'n punt wat nóg Rizzi (1997) nóg Beninca' \& Poletto (2004) uitwys. Die drie verskille - naamlik, die verpligte voorkoms van resumptiewe elemente by topikalisering, die nie-voorkoms van gefokaliseerde frases saam met wh-frases, en die nie-topikaliseerbaarheid van ongemodifiseerde kwantifiseerders - hang almal saam met verskuiwing en k-kommandering. Gegee die bogenoemde aanname dat getopikaliseerde frases basis-gegenereer word in die CP-domein, kan die verskille ten opsigte van verskuiwing en k-kommandering tussen Topiek- en Fokusfrases klaarblyklik saamgevat word as instansies van WCO-effekte. Op dié manier, dus, sou WCO kon dien om 'n beduidende veralgemening uit te druk.

\subsection{Beninca' \& Poletto se analise van Topiek en Fokus}

Beninca' \& Poletto (2004) se voorstelle vir die aanpassing van Rizzi (1997) se struktuur (33) van die CP-domein is gebaseer op die aanname dat Universele Grammatika nie voorsiening maak vir die rekursiwiteit van funksionele projeksies nie. Beninca' \& Poletto (2004:52) argumenteer dat "There is a one-to-one relation between position and function ... This means that recursion of a projection is not admitted." Aan die hand van Italiaanse data beskryf hulle beide Topiek en Fokus as "velde" en nie as twee enkele projeksies nie; meer spesifiek, hulle 
stel voor dat die verskillende tipes Topiek en Fokus van mekaar gedifferensieer word, en dat elkeen voorgestel word as 'n unieke funksionele hoof.

Die enkele Fokus-hoof in Rizzi (1997) se struktuur (33) word binne Beninca' \& Poletto (2004) se analise verdeel in drie afsonderlike Fokus-hoofde wat uitdrukking gee aan die onderskeiding tussen Informatiewe Fokus ("Informational Focus") en twee instansies van Kontrastiewe Fokus ("Contrastive Focus"). Informatiewe Fokus, aan die een kant, rig die hoorder se aandag op die een of ander entiteit of objek wat die spreker opvallend wil maak; die betrokke inligting is egter onafhanklik in die opsig dat dit nie saamhang met enige ander inligting in die konteks nie. Kontrastiewe Fokus, aan die ander kant, is informasioneel afhanklik: dit rig die hoorder se aandag op iets wat die spreker opvallend wil maak in verhouding met inligting wat gedeel word deur die gespreksgenote. Die onderskeiding tussen Informatiewe Fokus en Kontrastiewe Fokus word geïllustreer deur die voorbeelde in onderskeidelik (54a) en (54b).
a. (Wie huil?)
KAREN huil.
b. (Huil Karen?)
GRIET huil.

Gundel \& Fretheim (2004:180) karakteriseer die bogenoemde twee tipes Fokus soos volg: "One of these is relational - the information predicated about the topic [= Informatiewe Fokus]; the other is referential - material that the speaker calls to the addressee's attention, thereby often evoking a contrast with other entities that might fill the same position [= Kontrastiewe Fokus]." Wat Kontrastiewe Fokus betref, maak Beninca' \& Poletto (2004:61) die volgende aanname: "there must be at least two Contrastive Focus projections available in the $\mathrm{CP}$ structure: one hosting adverbs or objects, and one devoted to circumstantial and quantificational adverbs." Hulle stel vervolgens die struktuur in (55) voor. ${ }^{48}$

Die struktuur in (55) maak dit moontlik om 'n verklaring te gee vir die probleem met Rizzi se struktuur (33) wat in afdeling 3.3.2 hierbo uitgewys is. Dié probleem betref die grammatikali- 
teit van ' $\mathrm{n}$ sin soos die een in (43), hier herhaal as (56). Binne Rizzi se analise word voorspel dat sinne van hierdie tipe - waarin twee gefokaliseerde frases voorkom - ongrammatikaal moet wees aangesien die enkele FocP slegs een landingsplek bied vir sulke frases.

(56) Die $\operatorname{man}_{\mathrm{i}}$, gister ${ }_{\mathrm{j}}$, watter vrou het $\mathrm{hy}_{\mathrm{i}}\left(\text { toe }_{\mathrm{j}}\right)_{\text {vermoor? }}$

Volgens die struktuur in (55) kan die gefokaliseerde frase gister in (56) geanaliseer word as Kontrastiewe Fokus en die wh-frase watter vrou as Informatiewe Fokus. Let daarop dat só 'n analise versoenbaar is met Gundel \& Fretheim (2004:180) se karakterisering van Fokus hierbo: verskuifde wh-frases sal noodwendig Informatiewe Fokus moet wees omdat hulle altyd informasioneel onafhanklike inligting uitdruk. Hierdie siening word ondersteun deur die feit dat die lineêre volgorde [Top [FocP wh-frase [FocP ...]]] ontoelaatbaar is in Afrikaans, soos geïllustreer deur die ongrammatikaliteit van (57b).
a. Koos, gister, waarvan het hy gepraat?
b. *Koos, waarvan, gister het hy gepraat?

Beninca' \& Poletto (2004:63) tref verder 'n onderskeiding tussen verskillende tipes Topieke; volgens hulle is dit moontlik "to distinguish between two subfields in the Topic field: Hanging Topic and Left Dislocation." Hangende Topieke (HT) en Links-dislokasies (LD) is twee sintakties verskillende kategorieë ("thematized arguments", in Beninca' \& Poletto (2004:64) se terminologie) wat beide struktureel voorafgaan aan die Fokus-veld. Een van die sintaktiese verskille tussen HT en LD is dat "LD elements maintain the preposition of the internal elements they correspond to, but HTs can only be DPs." (Beninca' \& Poletto 2004:64). Hierdie verskil word geïllustreer deur die Italiaanse sinne in (58a,b); (58a) is 'n voorbeeld van 'n HT en (58b) van 'n LD.

(58) a. Mario, non ne parla piú nessuno.

Mario not of-him talks anymore nobody

'Mario, nobody talks of him anymore.'

b. Di Mario, non (ne) parla piú nessuno

of Mario not (of-him) talks anymore nobody

'Of Mario, nobody talks of him anymore.'

(Beninca' \& Poletto 2004:64) 
Beninca' \& Poletto (2004:65) stel dit verder dat HT en LD altyd in hierdie volgorde voorkom, soos geïllustreer deur die verskil in grammatikaliteit tussen die Italiaanse sinne in (59).

(59) a. Giorgio, ai nostri amici, non parlo mai di lui.

Giorgio to the our friends not talk ever of him

'Giorgio, to our friends, I never talk of him.'

b. *Ai nostri amici, Giorgio, non parlo mai di lui.

to our friends Giorgio not talk never of him

Afrikaans bevat oënskynlik nie grammatikale ekwivalente van die konstruksie in (58b) nie, soos geïllustreer deur die (b)-sinne hieronder.

(60) a. Arm mense, niemand voel iets vir hulle nie. (HT)

b. $\quad *$ Vir arm mense, niemand voel iets vir hulle nie. (LD)

(61) a. Marie, ek dans graag met haar. (HT)

b. *Met Marie, ek dans graag met haar. (LD)

Die ongrammatikaliteit van sinne soos (60b) en (61b) suggereer dat LD-konstruksies nie voorkom in Afrikaans nie. Tog is sinne soos die volgende, waarin sowel 'n LD as 'n HT voorkom, wel aanvaarbaar (of minstens marginaal aanvaarbaar):

(62) a. Gister, met Marie, ek het toe met haar gesels.

b. Die sleutels, in die laai, ek het hulle daarin gebêre.

Op grond van die verskil in grammatikaliteit tussen die (b)-sinne in (60) en (61) enersyds, en die sinne in (62) andersyds, kan die gevolgtrekking gemaak word dat LD's in Afrikaans slegs kan voorkom as die konstruksie ook 'n HT bevat. Let op dat die sinne in (62) die volgorde HT-LD vertoon, in ooreenstemming met Beninca' \& Poletto (2004:65) se voorstel. In Afrikaans, egter, is die omgekeerde volgorde ook aanvaarbaar, soos blyk uit die voorbeelde in $(63){ }^{49}$ 
(63) a. Met Marie, gister, ek het toe met haar gesels.

b. In die laai, die sleutels, ek het hulle daarin gebêre.

Beninca' \& Poletto (2004:64) stel dit verder dat dit moontlik is om meer as een LD te kry op die linkergrens van 'n sin, terwyl daar slegs een HT-element teenwoordig mag wees. Dit word geïllustreer deur die verskil in grammatikaliteit tussen die volgende Italiaanse sinne:

(64) a. *Gianni, questo libro, non ne hanno parlato a lui. (twee HT's) Gianni this book they of-it haven't talked to him

b. A Gianni, di questo libro, non gliene hanno mai parlato. (twee LD's) to Gianni of this book they of it haven't talked to him

'They did not talk to Gianni about this book.' ～(Beninca' \& Poletto 2004:64)

Hierbo is reeds gemeld dat konstruksies met 'n enkele LD - dit wil sê, sonder 'n gepaardgaande HT - nie voorkom in Afrikaans nie (kyk die (b)-sinne in (60) en (61)). Dit is skynbaar ook nie moontlik om meer as een LD in Afrikaans te hê nie, soos die ongrammatikaliteit van die volgende sinne toon:

(65) a. *Met Jan, oor die boeke, ek het met hom oor een gepraat.

b. *Vir Jan, aan die meisies, ek het vir hom aan hulle voorgestel.

Dit blyk verder dat Afrikaans, in teenstelling met Beninca' \& Poletto (2004:64) se algemene voorstel, nie die voorkoms van meer as een HT op die linkergrens uitsluit nie. Beskou die volgende sinne in hierdie verband:

(66) a. Pieter, sy vrou, jy moet hom van haar vertel.

b. Die regering, geld mors, hulle doen dit graag.

Volgens Beninca' \& Poletto (2004:64) is die gebruik van 'n resumptiewe element wat geassosieer is met 'n LD in sekere gevalle opsioneel: "LD elements require a resumptive pronoun only when they correspond to direct or partitive objects; the clitic is optional in the other cases." ${ }^{50}$ Hierdie beweerde eienskap van LD's geld klaarblyklik nie vir Afrikaans nie. Die sinne in (67) bevat byvoorbeeld albei 'n LD wat nie korrespondeer met 'n direkte objek 
nie; die weglating van die geassosieerde resumptiewe element lei in beide gevalle tot ongrammatikaliteit.

(67) a. Gister, oor hierdie saak, ek het toe met Jan *(daaroor) gepraat.

b. Jan, met die mes, ek het hom *(daarmee) gedreig.

Om saam te vat: Hierbo is 'n uiteensetting gegee van Beninca' \& Poletto (2004) se voorstelle oor die onderskeiding tussen verskillende Topiek-velde en Fokus-velde. In die bespreking is daar aangetoon dat die betrokke voorstelle nie almal geld vir Afrikaans nie. Wat betref die voorstelle in verband met die Fokus-veld, geld die gevolgtrekkings in (68) vir Afrikaans; die gevolgtrekkings in verband met die Topiek-veld in Afrikaans word in (69) saamgevat.

(68) a. 'n Sintaktiese onderskeiding kan gemaak word tussen Kontrastiewe Fokus en Informatiewe Fokus.

b. Dié onderskeiding hang saam met die feit dat Kontrastiewe Fokus struktureel voorafgaan aan Informatiewe Fokus.

(69) a. 'n Sintaktiese onderskeiding kan gemaak word tussen Hangende Topieke en Links-dislokasies.

b. Dié onderskeiding hang saam met die feit dat LD's nie alleen - dit wil sê sonder 'n gepaardgaande HT - kan voorkom nie.

c. HT's kan wel sonder gepaardgaande LD's voorkom.

d. Slegs een LD mag voorkom in die CP-domein; hierdie beperking geld nie vir HT's nie.

e. Daar is nie 'n beperking op die lineêre volgorde van LD's en HT's nie.

f. Sowel LD's as HT's is verplig geassosieer met resumptiewe elemente.

Die gevolgtrekkings in (69b,d-f) is strydig met Beninca' \& Poletto (2004) se voorstelle. Dit kan dui op 'n aantal parametriese verskille tussen Afrikaans en die Italiaanse dialekte waarop Beninca' \& Poletto (2004) hulle voorstelle grond. Op basis van die gevolgtrekkings in (68) en (69) is die volgende konfigurasies moontlik binne die Afrikaanse CP-domein: ${ }^{51}$ 
(70)

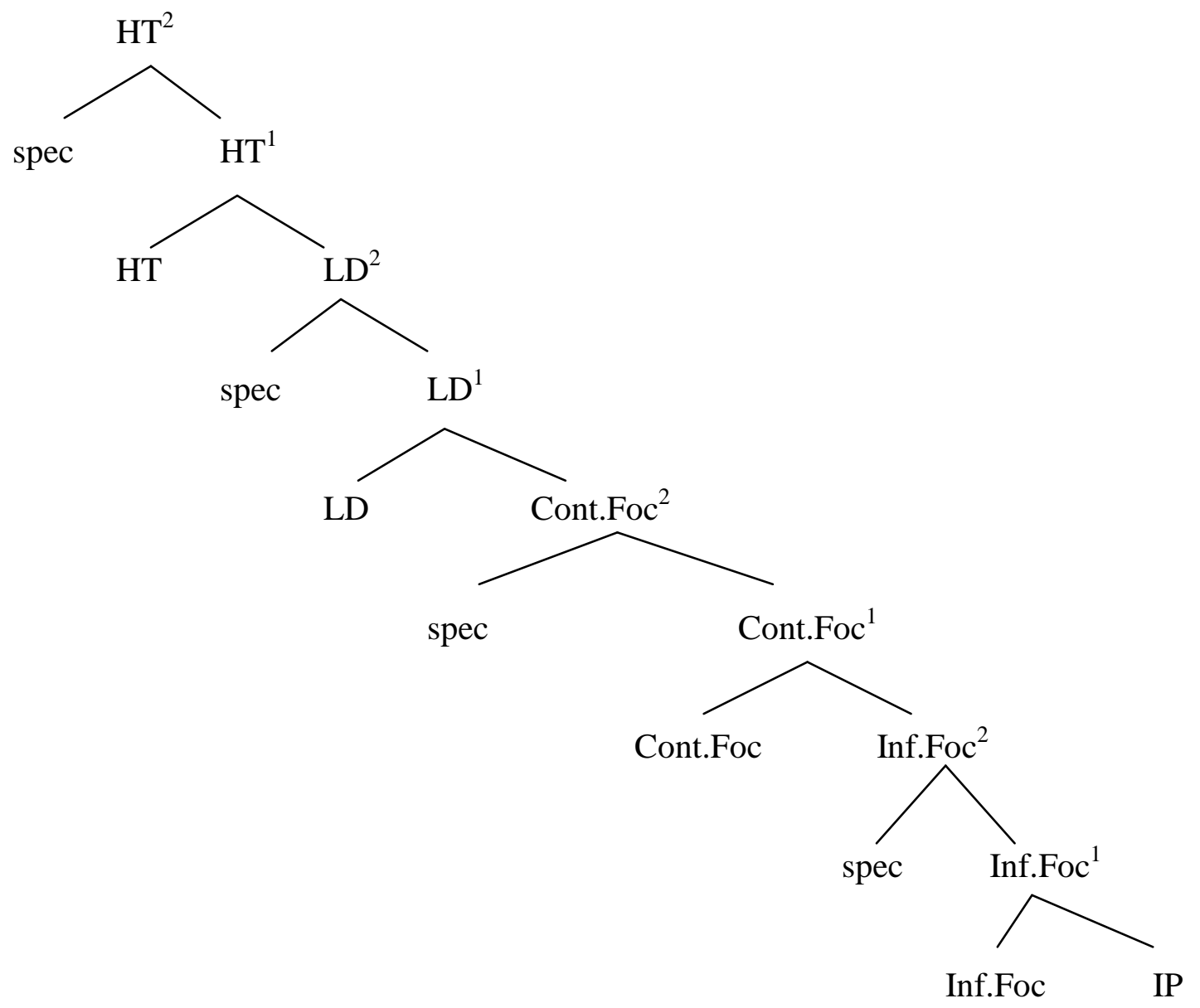


(71)

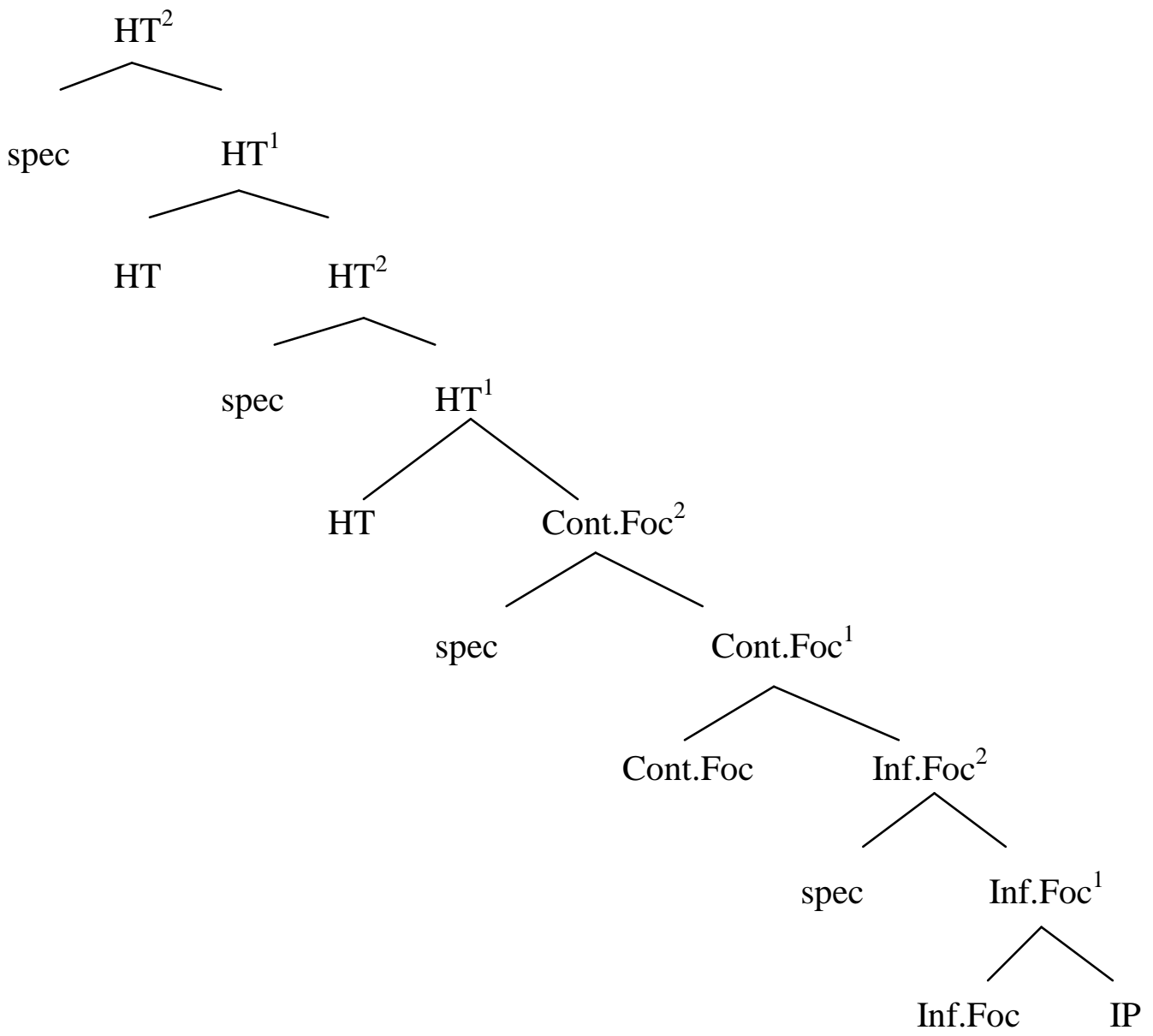


(72)

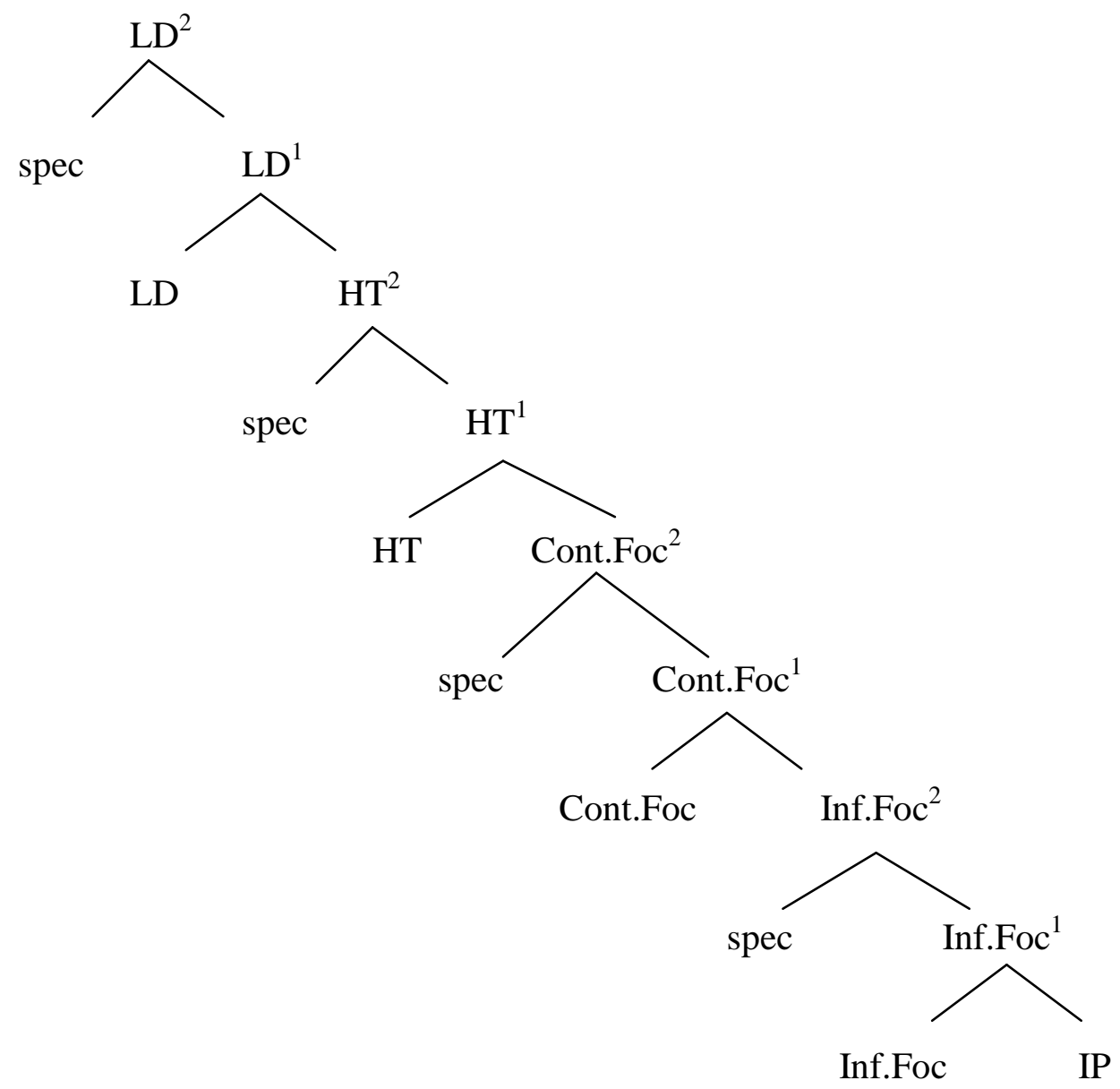

(73)

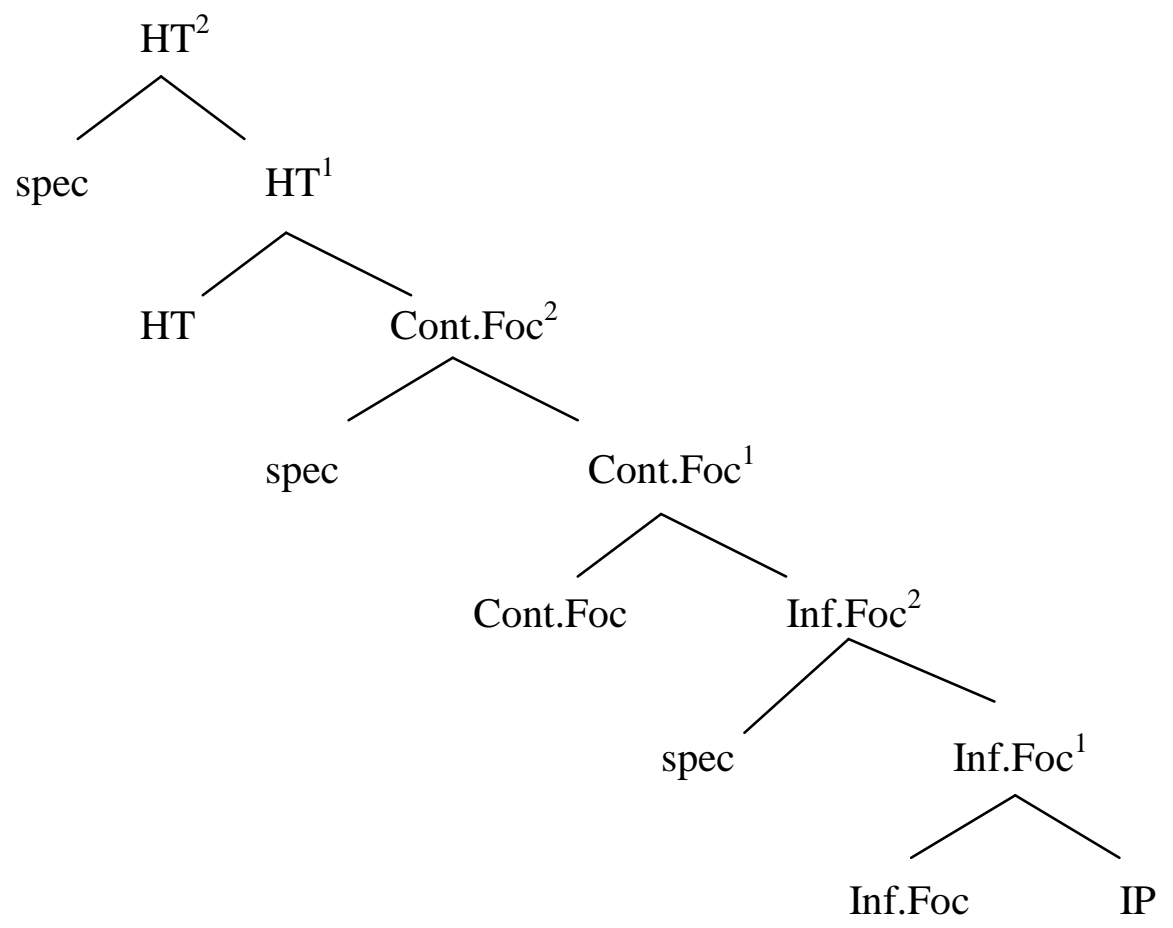


Met verwysing na data uit Italiaans en Reto-Romaans suggereer Beninca' \& Poletto (2004:6670) twee verdere verfynings binne die CP-domein. Beskou eerstens die volgende voorbeelde uit Reto-Romaans (die hoofletters dui op kontrastiewe klem):

a. DUMAN va-al a Venezia.

TOMORROW goes-he to Venice

'He is going to Venice tomorrow.'

b. Duman va-al a Venezia.

tomorrow goes-he to Venice

'He is going to Venice tomorrow.'

(Beninca' \& Poletto 2004:66)

Die tydsadverbiaal duman in (74) word op twee verskillende maniere verstaan. Beninca' \& Poletto (2004:66) stel dit dat "the two occurrences of the temporal adverb duman in [(74a,b)] are not located in the same position: in [(74a)] the adverb is contrastively focalized, but in [(74b)] it is not." Volgens hulle het dié verskil - wat foneties uitgedruk word - 'n sintaktiese basis: in Reto-Romaans kan net Kontrastiewe Fokus voorkom in ingebedde V2-sinne, soos die verskil in grammatikaliteit tussen $(75 a, b)$ toon.

(75) a. Al m a dit c DUMAN va-al a Venezia.

he me has told that tommorow goes-he to Venice

'He told me that he is going to Venice tomorrow.'

b. *Al m a dit c duman va-al a Venezia.

he me has told that tomorrow goes-he to Venice (Beninca' \& Poletto 2004:66)

Die sintaktiese verskil tussen die twee interpretasies van die tydsadverbiaal wat geïllustreer word in (75) dui volgens Beninca' \& Poletto (2004:66) op 'n onderskeiding tussen twee verskillende tipes funksionele hoofde. In (75a), enersyds, staan die tydsadverbiaal duman in die Kontrastiewe Fokus-veld. In (75b), andersyds, staan dit in die Topiek-veld in wat Beninca' \& Poletto (2004:66-67, 71) 'n "scene setting position" noem, klaarblyklik die spesifiseerderposisie van 'n afsonderlike funksionele hoof Toneelskets ("Scene Setting").

In Afrikaans lei die voorkoms van adverbiale in die Topiek-veld oënskynlik tot sinne wat ongrammatikaal is, hoewel sommige sprekers sulke uitings as marginaal aanvaarbaar beskou 
indien die adverbiaal kontrastiewe klem ontvang. Beskou die volgende voorbeelde ter illustrasie:

(76) a. ?? MÔRE / * Môre, ek gaan dan strand toe. (Tyd)

b. $\quad$ ??SAGGIES / *Saggies, hy praat so met haar. (Wyse)

Voorts geld die sintaktiese onderskeiding tussen die twee verskillende soorte interpretasies van 'n tydsadverbiaal, soos geïllustreer deur die Reto-Romaanse sinne in (75), klaarblyklik nie vir Afrikaans nie. Die sinne in (77) is byvoorbeeld ongrammatikaal, ongeag of die adverbiaal 'n Kontrastiewe Fokus-interpretasie kry of nie.

(77) a. *Ek dink MÔRE / môre, ek gaan dan strand toe.

b. $\quad *$ Hy vermoed SAGGIES / saggies, hy sal so met haar praat.

Beninca' \& Poletto (2004:67-70) se tweede suggestie in verband met die verfyning van die CP-domein behels die onderskeiding tussen Links-dislokasies en elemente wat 'n sogenaamde Lys-interpretasie ("List Interpretation", LI) kry. Beide vorm deel van die Topiek-veld. Beninca' \& Poletto (2004:67) omskryf Lys-interpretasie as "the case in which two elements belonging to the same list of already known items are contrasted." Hierdie soort interpretasie kan geïllustreer word met die volgende voorbeeld:

(78) Die appels, ons verkoop dit, maar die lemoene, julle kan dit verniet kry.

Volgens Beninca' \& Poletto (2004:68) vereis die interpretasie van 'n LI "shared knowledge of the speaker and the hearer [that] is not accessible in the immediate context so that it cannot be recovered"; LD-elemente, daarenteen, "can be recovered from the immediate context."

Een van die sintaktiese toetse vir 'n LI-interpretasie is die vervanging van die betrokke elemente met die vaste uitdrukking eersgenoemde ... laasgenoemde, soos in (79). Hierdie soort vervanging is uiteraard nie moontlik in die geval van 'n LD-element wat nie deel vorm van 'n lys nie.

(79) Eersgenoemde, ons verkoop dit, maar laasgenoemde, julle kan dit verniet kry. 
Die twee verfynings van die CP-domein wat hierbo kortliks beskryf is, word nie verder in hierdie artikel bespreek nie. Beninca' \& Poletto self brei nie in enige besonderhede uit oor Toneelskets en Lys-interpretasie as moontlike afsonderlike funksionele kategorieë nie. Wat eersgenoemde betref, volstaan hulle (2005:67) met die opmerking "we will leave the matter of an independent Scene Setting position open." Wat die onderskeiding tussen LI-elemente en LD-elemente in die Topiek-veld betref, maak hulle (2005:70) die volgende tentatiewe voorstel: "we define the position(s) before LI as LDTopics, in order to distinguish them from HT, but we would like to have a more solid empirical basis to be able to make further, finer distinctions. Therefore, for the moment, we leave the matter at this point, proposing the following section of CP structure: ... [LD [LI [Focus ...]]]".

\subsection{Rizzi se analise van Krag en Finietheid}

In afdeling 3.1 is genoem dat die komplementeerdersisteem 'n sin as geheel kontekstualiseer; Rizzi (1997:283) stel dit dat "We can think of the complementizer system as the interface between a propositional content (expressed by the IP) and the superordinate structure (a higher clause or, possibly, the articulation of discourse, if we consider a root clause)." Die Csisteem verskaf dus twee soorte inligting: aan die een kant diskoers-relevante inligting, dit wil sê, inligting wat "na buite" die sin gerig is, en aan die ander kant sintakties-relevante inligting, dit wil sê, inligting wat "na binne", na die IP/TP, gerig is.

In terme van Rizzi se struktuur in (33), hier herhaal as (80), is die heel hoogste projeksie in die C-domein die Krag-frase ("Force Phrase", ForP), en die heel laagste die Finietheid-frase ("Finiteness Phrase", FinP).

$$
[\text { ForP [TopP* [FocP [TopP* [FinP [IP ...]]]]]] }
$$

(Rizzi 1997:297)

Die bespreking tot dusver in afdeling 3 het gefokus op die Topiek-Fokus-sisteem as 'n raamwerk om die verhouding tussen ou en nuwe inligting sintakties te enkodeer. Buiten hierdie funksie, moet die C-sisteem ook die sinstipe ("clausal Type") weergee; soos Rizzi (1997:283) dit stel: "Complementizers express the fact that a sentence is a question, a declarative, an exclamative, a relative, a comparative, an adverbial of a certain kind, etc." Hierdie soort inligting is wat Chomsky (1995:240) die spesifikasie van Krag ("specification of 
Force") noem. Binne Rizzi se struktuur (80) vorm Krag die mees linkse funksionele hoof binne die CP-sisteem; dit is dan die plek waar die pragmatiese konteks waarin die sin geplaas is, sintakties uitgedruk word. Die spesifieke Krag van 'n sin kan weergegee word deur 'n overte Krag-hoof of deur 'n element wat in die spesifiseerderposisie van so 'n hoof staan. Volgens Rizzi (1997:325) is die komplementeerders that in Engels en que in Frans voorbeelde van Krag-hoofde (omdat hulle die struktuur as 'n stelsin merk); daarenteen staan relatiewe voornaamwoorde in die spesifiseerderposisie van Krag. Gegee hierdie voorstelle, sal dat en of dus as Krag-hoofde geklassifiseer kan word in Afrikaans, en relatiewe voornaamwoorde soos wie en wat as elemente wat die spesifiseerderposisie van die Krag-hoof vul. Dit moet egter genoem word dat Rizzi (1997) en ander navorsers oor die CP-domein, soos Beninca' \& Poletto (2004), opvallend min aandag gee aan die kategorie Krag.

Ook oor die kategorie Finietheid is daar min konkrete voorstelle in die literatuur. Dié kategorie druk die verband uit tussen, onder meer, die tempuskenmerke van ' $\mathrm{TP}$ en die CPdomein self. Zwart (1993:160) bied talle voorbeelde uit Fries en verskeie Nederlandse dialekte wat die noue verband tussen die C-sisteem en die TP illustreer. In al hierdie voorbeelde stem die komplementeerder morfologies ooreen met die tempusvorm van die werkwoord. In Zwart (1993:161) se woorde, "In these dialects the agreement morpheme on the complementizer is identical to the agreement morpheme on the verb", soos geillustreer deur die Friese voorbeelde in (81).

$$
\begin{aligned}
& \text { a. ...datst (do) jûn komst } \\
& \text { dat-2SG jy vanaand kom-2SG } \\
& \text { b. } \quad \text {...dat (er) jûn komt } \\
& \text { dat hy vanaand kom-3SG }
\end{aligned}
$$

Binne Rizzi se raamwerk bevat die Fin-hoof klaarblyklik 'n spesifikasie wat bepaal of sy TPkomplement finiet of infinitief moet wees. Die C-sisteem moet dus sekere finietheidkenmerke bevat wat verband hou met die TP se tempus en geassosieerde onderskeidings, byvoorbeeld subjek-werkwoord-kongruensie en Modus (indikatief, subjunktief, kondisioneel, ens.). Rizzi (1997:284) stel dit dat "we should think of finiteness as the core IP-related characteristics (sic) that the complementizer system expresses", waar finietheid "more rudi- 
mentary than tense" is. Die feit dat Fin saamhang met die tempus van die sin kan geïllustreer word deur die sinne in (82). ${ }^{52}$

(82) a. Ek weet [ForP dat [+ Fin] [TP hulle môre kom]].

b. *Ek weet [ForP dat [+ Fin] [TrP hulle môre te kom]].

c. Hulle sal probeer [ForP om [- Fin] [TP môre te kom]].

d. *Hulle sal probeer [[ForP om [- Fin] [TP môre gekom het]].

Die ongrammatikaliteit van $(82 \mathrm{~b}, \mathrm{~d})$ spruit daaruit dat die finietheid-kenmerke (dit wil sê, [ \pm Fin] ) van die onderskeie Fin-hoofde nie ooreenstem met dié van hul komplement-TP's nie.

\subsection{Enkele afleidings}

Die eerste sistematiese en omvattende ondersoek na die interne struktuur van die CP-domein was dié van Rizzi (1997). ${ }^{53}$ Rizzi se analise hou in dat die enkele C-hoof in vier funksionele hoofde verdeel word, elk met sy eie projeksie: Topiek, Fokus, Krag, en Finietheid. Beninca' \& Poletto (2004) bou voort op hierdie verdeling, en stel verskeie verdere verfynings voor in verband met die Topiek- en Fokus-projeksies. Die voorstelle van Rizzi (1997) en Beninca' \& Poletto (2004) is uiteengesit in afdelings 3.3-3.5 hierbo, en daar is telkens nagegaan of die betrokke voorstelle ook geld vir Afrikaans. In die huidige afdeling word die voorafgaande bevindings geïllustreer aan die hand van enkele afleidings van Afrikaanse sinne, spesifiek sinne waarin een of meer van die voorgestelde projeksies binne die CP-domein geaktiveer is. Geriefshalwe word daar in die afleidings hieronder nie in enige detail ingegaan op die interne struktuur van TP nie; die afleiding van verskillende instansies van TP is reeds geïllustreer in afdeling 2. Afdeling 3.6 handel dus slegs oor die bewerkings wat direk verband hou met die CP-domein.

Beskou eerstens die afleiding van die sin in (83), weergegee in diagram (84), ${ }^{54}$ in hierdie geval bevat die sin 'n enkele gefokaliseerde frase.

Rooiwyn drink ek dikwels. 


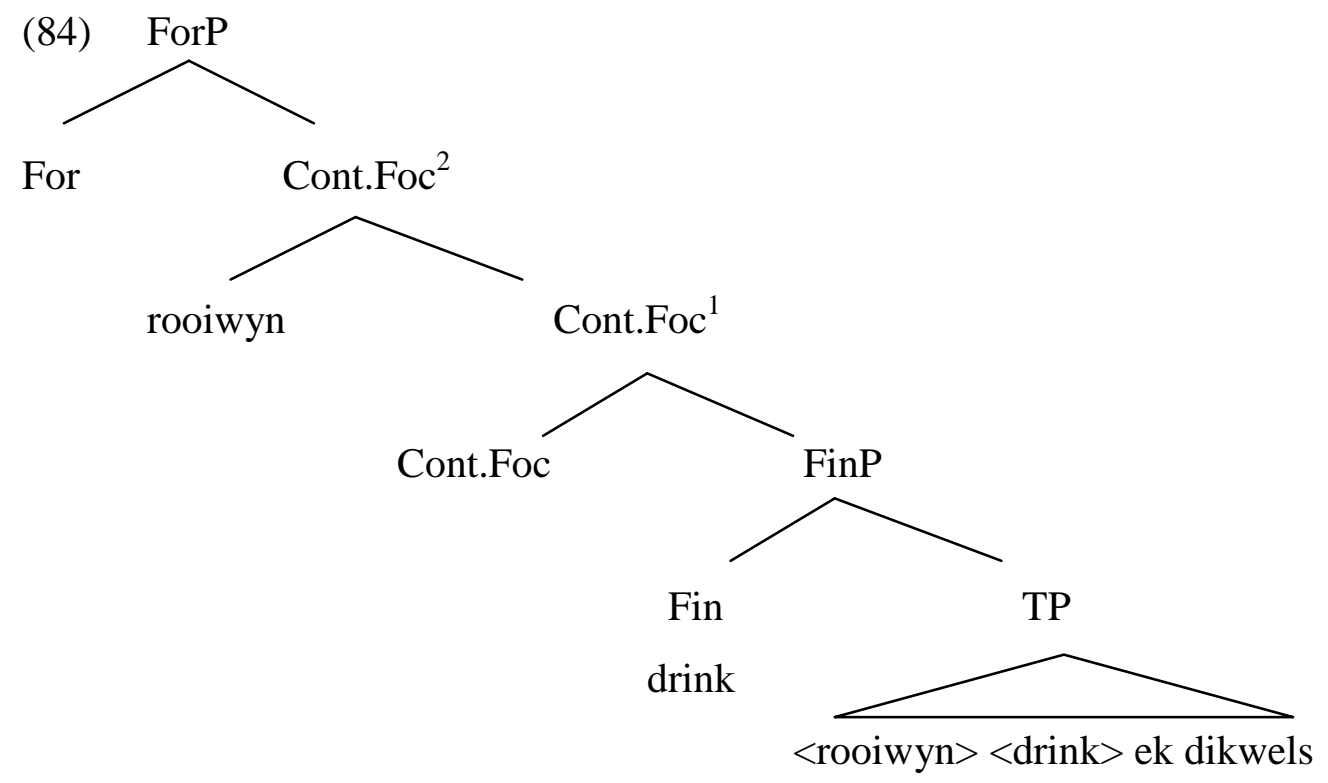

In afdeling 3.3.1 is genoem dat fokalisering altyd gepaardgaan met inversie van die subjek en die finiete werkwoord. Die vraag onstaan nou waarom verpligte inversie plaasvind in die geval van fokalisering. In die lig van die bespreking van Finietheid in afdeling 3.5 hierbo, word die volgende voorstel gemaak: indien die Fokus-veld geaktiveer is, selekteer die Fochoof 'n Fin-hoof met 'n sterk kenmerk wat die IS van die finiete werkwoord en die Fin-hoof afdwing. ${ }^{55}$ Dus sal 'n Foc-hoof noodwendig saam met 'n sterk Fin-hoof voorkom. Let ook op dat die gefokaliseerde frase rooiwyn in (83) as gevolg van IS vooropgestel is in die spesifiseerderposisie van Cont.Foc. Die Cont.Foc-hoof self bevat klaarblyklik 'n sterk kenmerk wat afgemerk moet word deur die een of ander kenmerk van die gefokaliseerde frase. Die vraag of so 'n kenmerk 'n formele kenmerk is, en of dit eerder beskou moet word as 'n diskoers-semantiese kenmerk, val buite die bereik van hierdie artikel.

Beskou tweedens die afleiding van die sin in (85), skematies voorgestel in (86). In hierdie geval verteenwoordig rooiwyn 'n getopikaliseerde frase, soos blyk uit die (verpligte) voorkoms van die resumptief dit en die feit dat inversie nie plaasgevind het nie.

(85) Rooiwyn, ek drink dit dikwels. 
(86) ForP

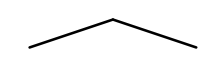

For

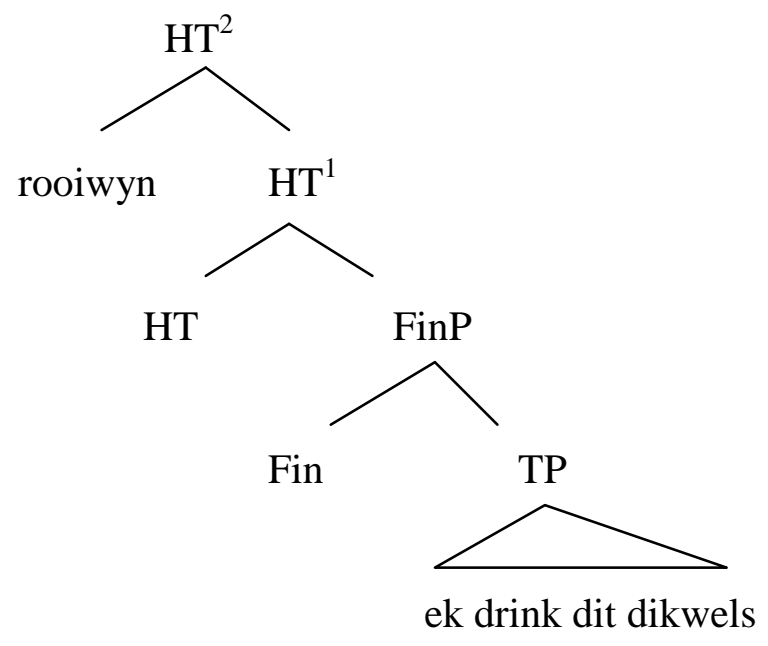

In afdeling 3.3.1 is dit duidelik gemaak dat topikalisering nie gepaard kan gaan met subjekwerkwoord-inversie in Afrikaans nie. Die voor die hand liggende vraag is nou waarom inversie uitgesluit is in die geval van topikalisering. In die lig van die bespreking van Finietheid in afdeling 3.5 hierbo, kan die volgende tentatiewe voorstel in dié verband gemaak word: indien die Topiek-veld geaktiveer is, selekteer die Topiek-hoof 'n Fin-hoof met 'n swak kenmerk. ${ }^{56}$ Die Fin-hoof dwing dus nie IS met die finiete werkwoord af nie, en die woordorde bly onveranderd. Hieruit volg dit dat Topiek-hoofde altyd voorkom saam met swak Finhoofde, en Fokus-hoofde saam met sterk Fin-hoofde. In sinne soos (87) hieronder, waar die CP-domein sowel 'n getopikaliseerde frase as 'n gefokaliseerde frase bevat, word die Fin-hoof geselekteer deur die Fokus-hoof; in so 'n geval sal die Fin-hoof dus sterk wees. In die geval van (85) is die getopikaliseerde frase rooiwyn deur ES gegenereer in die spesifiseerder-posisie van die HT-hoof; dit wil sê, geen IS (verskuiwing) het plaasgevind nie. Die aanname is dat die HT-hoof 'n "Topiek-kenmerk" dra wat afgemerk moet word deur die een of ander kenmerk van die getopikaliseerde frase.

Beskou derdens die afleiding van die sin in (87), voorgestel in diagram (88); dié sin bevat sowel 'n Topiek- as 'n Fokus-frase. Inversie dui aan dat fokalisering plaasgevind het, terwyl die aanwesigheid van die resumptief dui op topikalisering.

(87) Die nuus, vandag moet jy dit kyk. 

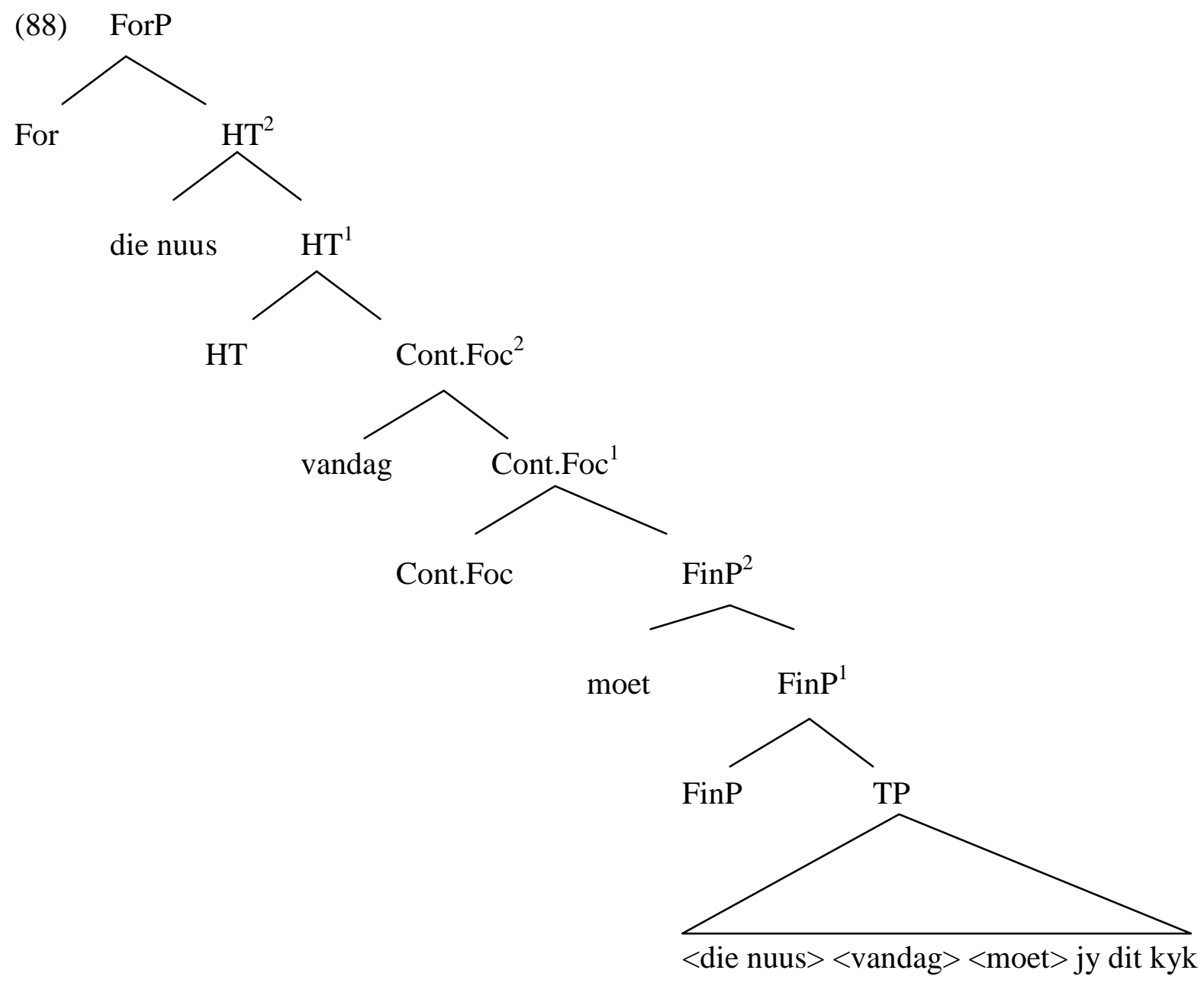

Beskou vierdens die sin in (89); in hierdie geval kom daar twee gefokaliseerde frases voor (môre en hoe laat) saam met 'n getopikaliseerde frase (die fliek). Die afleiding van sin (89) word skematies weergegee in (90). ${ }^{57}$

(89) Die fliek, môre, hoe laat wys dit? 
(90) ForP

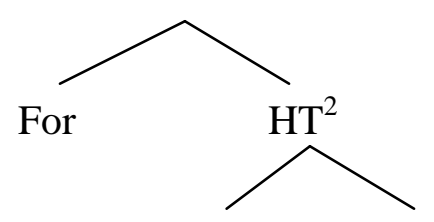

die fliek
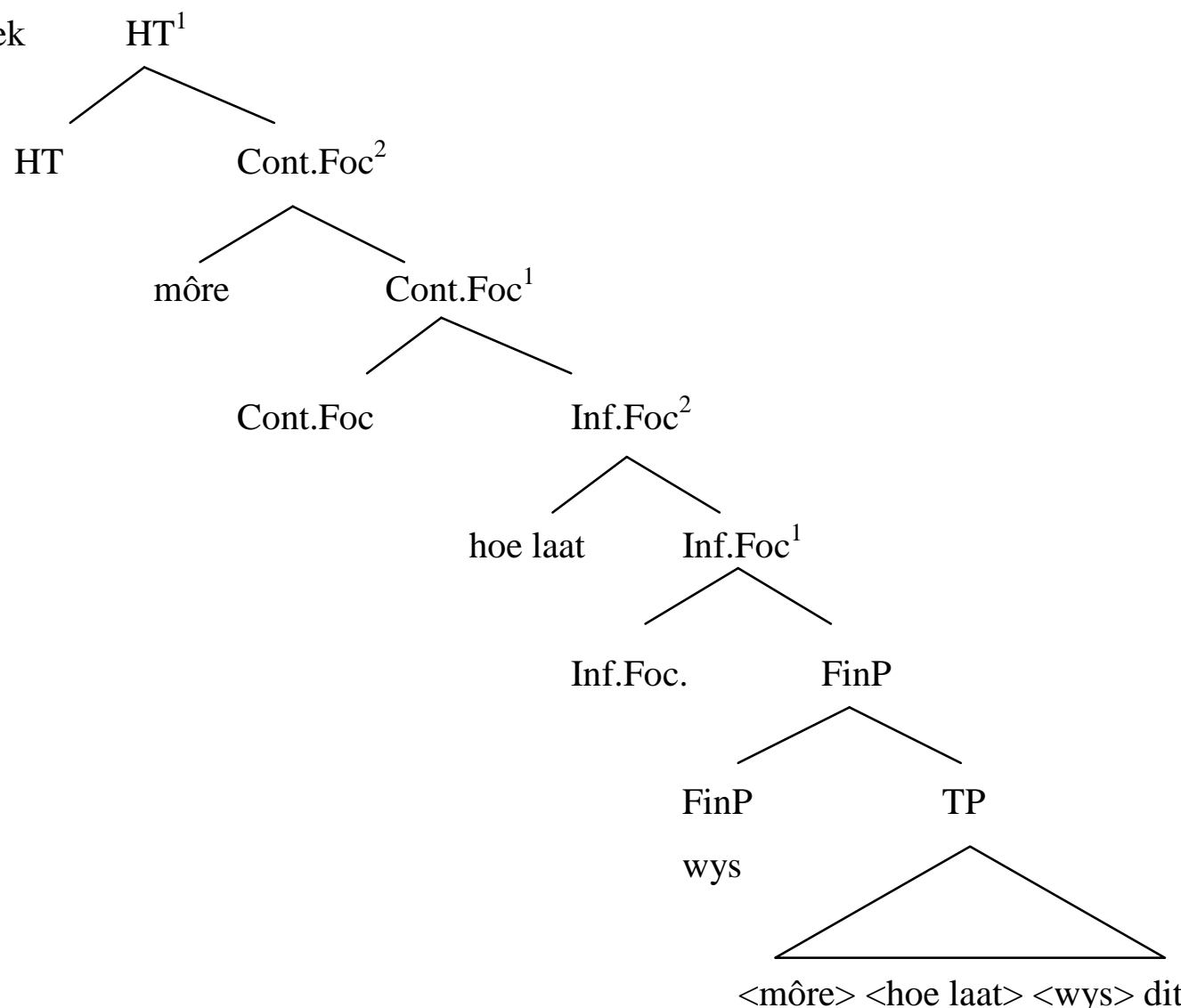

Beskou vyfdens die sin in (91) wat 'n HT sowel as 'n LD bevat. Die afleiding van die sin word weergegee in die diagram in (92). ${ }^{58}$

(91) Gister, met daardie student, ek het toe met hom gepraat. 


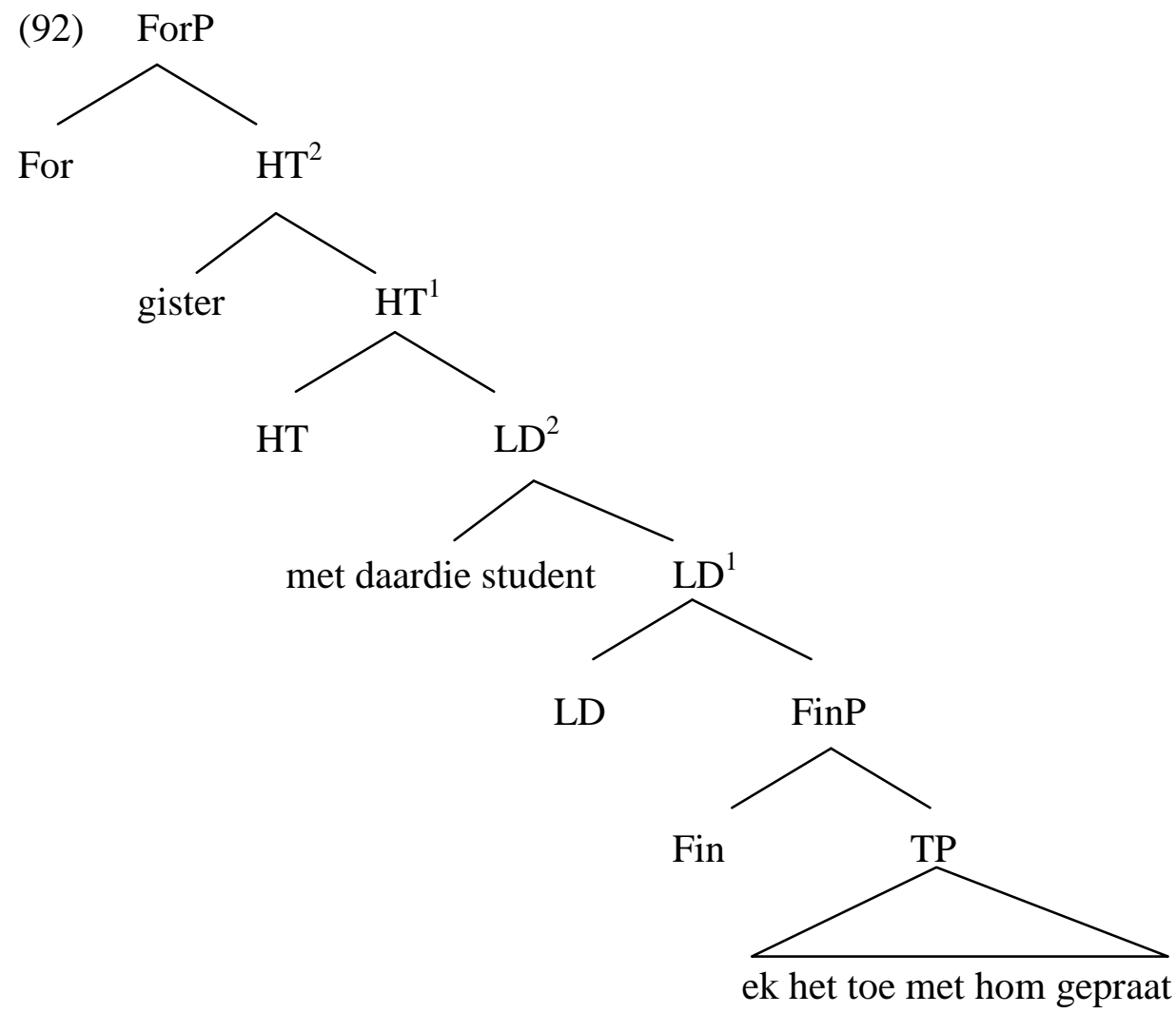

Beskou vervolgens die afleiding van die sin in (93), weergegee in diagram (94). Dié sin bevat die overte For-hoof dat wat die sin se Krag merk as eksklamatief (dit wil sê, 'n uitroep).

(93) Dat ek nou dit ook nog moet hanteer!

(94) ForP

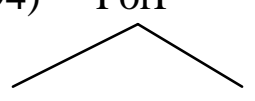

For

FinP

dat
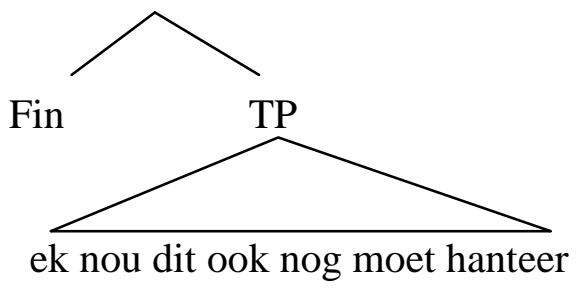

Beskou laastens die sin in (95). Die reeks met wie jy nou net gepraat het is 'n relatiewe bysin wat ingelei word deur die PP met wie, waar wie 'n relatiewe voornaamwoord verteenwoordig. Die afleiding van die relatiefsin in (95) word voorgestel in diagram (96). ( $\mathrm{TP}^{1}$ in (96) is die $\mathrm{TP}$ van die hoofsin en $\mathrm{TP}^{2}$ dié van die relatiefsin.) 
(95) (Ek ken) daardie man met wie jy nou net gepraat het.
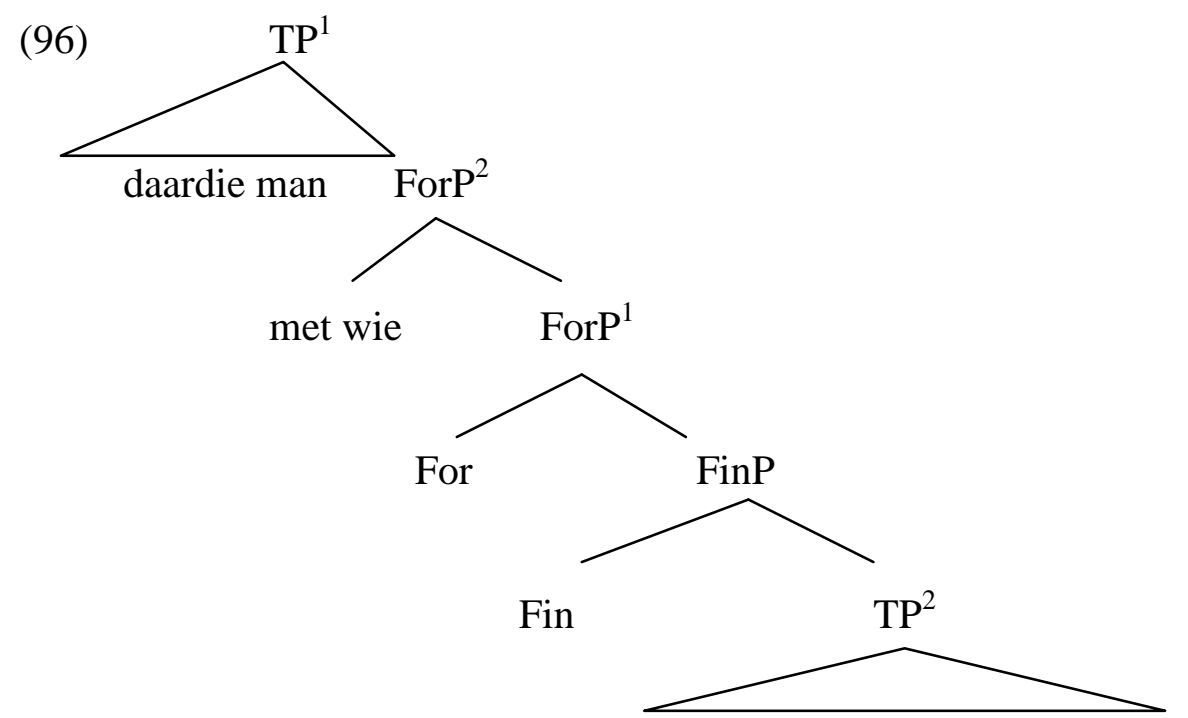

jy nou net gepraat het <met wie>

Die vraag onstaan nou waarom die wh-frase met wie in die relatiefsin verskuif is na die spesifiseerderposisie van For en nie, soos in die afleiding van wh-vraagsinne, na die spesifiseerderposisie van 'n Inf.Foc-hoof nie (kyk afdeling 3.4). Indien die wh-frase in 'n relatiefsin inderdaad na 'n Fokus-posisie verskuif word, sou subjek-werkwoord-inversie moet plaasvind in die afleiding van sulke bysinne, aangesien dit een van die kenmerkende eienskappe van fokalisering is. In (95) het inversie egter nie plaasgevind nie; trouens, relatiefsinne wat inversie vertoon is altyd ongrammatikaal, soos geillustreer in (97).

(97) a. [Die beker] waaruit ek drink.

b. $\quad *[$ Die beker] waaruit drink ek.

Gevolglik kan die vooropstelling van wh-frases in die afleiding van relatiefsinne nie 'n geval van fokalisering wees nie.

\section{Samevatting en gevolgtrekkings}

Die kartering van die fyn struktuur van funksionele domeine het ontwikkel tot 'n vrugbare terrein van ondersoek in generatiewe sintaksis oor die afgelope 25 jaar. Ondersoeke na die 
interne struktuur van byvoorbeeld die DP- en die TP-domein het gelei tot meer toereikende beskrywings van afsonderlike tale en ook tot insiggewende vergelykende studies. In hierdie artikel is gefokus op die interne struktuur van die funksionele domein wat konvensioneel bekend staan as die CP, en in besonder die CP-domein in Afrikaans. Die doel van die ondersoek was om te bepaal of die invloedryke voorstelle van Rizzi (1997) - bekend as die Verdeelde-CP-hipotese - en die daaropvolgende aanpassings van dié hipotese deur Beninca' \& Poletto (2004) ook geld vir die beskrywing van die CP-domein in Afrikaans. Soos gemeld in afdeling 1, was die spesifieke oogmerk om antwoorde te kry op die volgende vrae:

A. Bied die Verdeelde-CP-hipotese 'n toereikende raamwerk vir die beskrywing van die CP-domein in Afrikaans?

B. Indien nie, hoe sou (spesifieke onderdele van) hierdie hipotese aangepas kon word om die feite van Afrikaans te akkommodeer?

Die ondersoek na die meriete van die (aangepaste) Verdeelde-CP-hipotese is uitgevoer binne die teoretiese raamwerk van Minimalistiese Sintaksis. Enkele aannames en meganismes van MS is uiteengesit in afdeling 2 en toegelig met Afrikaanse voorbeelde.

Die inhoud van en die vernaamste besware teen die standaard GB-analise van die CP is kortliks bespreek in afdelings 3.1 en 3.2. In die res van afdeling 3 is 'n uiteensetting gegee van eerstens Rizzi (1997) se Verdeelde-CP-hipotese, en tweedens Beninca' \& Poletto (2004) se voorgestelde aanpassings van hierdie hipotese. Die Verdeelde-CP-hipotese hou in dat die enkele C-hoof verdeel word in vier afsonderlike funksionele hoofde, elk met sy eie projeksie, naamlik Krag, Topiek, Fokus en Finietheid. Volgens Rizzi (1997:297) vorm Krag die "hoogste" funksionele hoof in sinstruktuur, gevolg deur Topiek, Fokus en Finietheid in hierdie volgorde. Dit is egter belangrik om daarop te let dat Topiek 'n rekursiewe kategorie is wat hiërargies gesproke sowel direk bo as direk onder Fokus kan voorkom. Die fyn struktuur van die CP-domein kan dus volgens Rizzi soos volg voorgestel word (waar die asterisk * dui op rekursiwiteit): 
In afdeling 3.3 is vier sintaktiese oorwegings bespreek wat Rizzi (1997) aanbied ter ondersteuning van spesifiek die onderskeiding tussen Topiek en Fokus as afsonderlike funksionele hoofde. Dié oorwegings hou verband met resumptiewe voornaamwoorde (3.3.1), voorkoms saam met wh-frases (3.3.2), ongemodifiseerde kwantifiseerders (3.3.3), en Swak Oorkruising (3.3.4). In afdeling 3.3.4 is die volgende gevolgtrekking gemaak in verband met hierdie vier oorwegings: Die betrokke sintaktiese verskille tussen Topiek en Fokus kan klaarblyklik saamgevat word as instansies van Swak Oorkruising (WCO)-effekte, en hierdie effekte kan beskryf word in terme van verskuiwing en k-kommandering. WCO sou dus kon dien om 'n beduidende veralgemening uit te druk.

Die voorstel dat Topiek 'n rekursiewe kategorie is wat boonop verskillende posisies kan inneem relatief tot Fokus, maak dit natuurlik moeilik om presiese voorspellings te maak oor lineêre volgorde binne die CP-domein. Beninca' \& Poletto (2004:52) maak die volgende opmerkings in hierdie verband:

The cartographic project that aims to analyze the fine structure of the $\mathrm{CP}$ domain is based on the fundamental idea that the number of FPs [= functional projections] present in the syntactic structure is finite and that each syntactic projection has its own special syntactic and semantic properties. In such a framework, it seems to us, there is no space for recursion.

Beninca' \& Poletto (2004:53) stel voorts die volgende aanpassings voor van Rizzi se Verdeelde-CP-hipotese. Eerstens word Topiek nie geanaliseer as 'n rekursiewe kategorie nie, en tweedens vertoon Topiek en Fokus 'n vaste hiërargie, met Topiek bokant Fokus. Derdens stel Beninca' \& Poletto (2004) voor dat sowel Topiek as Fokus geanaliseer word as "velde" en nie as enkele, ongedifferensieerde hoofde nie. In die Topiek-veld postuleer hulle minstens vier gespesialiseerde hoofde, naamlik Hangende Topiek (HT), Links-dislokasie (LD), Lysinterpretasie (LI), en Toneelskets (LS). In die Fokus-veld postuleer hulle drie moontlike gespesialiseerde hoofde, naamlik 'n Informatiewe Fokus-hoof (Inf.Foc) en twee Kontrastiewe Fokus-hoofde (Cont.Foc). ${ }^{59}$

In die loop van die bespreking in afdelings 3.3-3.5 is geargumenteer dat die voorstelle vervat in Rizzi (1997) se Verdeelde-CP-hipotese, soos aangepas deur Beninca' \& Poletto (2004), 
grotendeels ook vir Afrikaans geld. Die vernaamste bevindings in hierdie verband kan geriefshalwe soos volg saamgevat word:

(99) In Afrikaans kan die C-hoof in vier afsonderlike funksionele hoofde verdeel word, elk met sy eie projeksie - naamlik Krag, Topiek, Fokus en Finietheid, in hierdie volgorde. Dit is moontlik dat al vier dié hoofde gelyktydig kan voorkom in die uitgebreide CPdomein.

(100) Krag is die plek waar die pragmatiese konteks waarin die sin geplaas is, sintakties uitgedruk word - byvoorbeeld of die sin funksioneer as 'n stelsin, 'n vraagsin, 'n eksklamatief, ens. Komplementeerders soos dat en of tree op as Krag-hoofde. Whfrases (insluitend relatiewe voornaamwoorde) wat met relatiefsinne geassosieer word, kom voor in die spesifiseerderposisie van Krag.

(101) a. Topiek is ' $n$ sintaktiese veld waarin inligting wat reeds bekend is binne die voorafgaande diskoers, weergegee word. Die Topiek-veld sluit ten minste twee afsonderlike hoofde in, naamlik Hangende Topiek (HT) en Links-dislokasies (LD). ${ }^{60}$

b. HT's mag alleen voorkom, terwyl 'n LD nie sonder 'n HT mag voorkom nie.

c. Daar mag net een LD voorkom in die Topiek-veld, terwyl geen sodanige beperking geld vir HT's nie.

d. Daar is nie 'n beperking op die lineêre volgorde van LD's en HT's nie.

e. Sowel LD's as HT's is verplig geassosieer met resumptiewe elemente.

(102) a. Fokus is 'n sintaktiese veld waarin nuwe inligting weergegee word, dit wil sê, inligting wat nie beskikbaar is in die voorafgaande diskoers nie. Die Fokus-veld sluit ten minste drie afsonderlike hoofde in, naamlik twee Kontrastiewe Fokushoofde en 'n Informatiewe Fokus-hoof. ${ }^{61}$

b. Die verskillende hoofde in die Fokus-veld mag saam voorkom, maar dan altyd in die lineêre volgorde [Cont.Foc - Inf.Foc].

c. Vooropgestelde wh-frases kom altyd voor in die spesifiseerderposisie van Inf.Foc.

d. 'n Fokus-hoof selekteer 'n Finietheid-hoof met 'n sterk Fin-kenmerk, wat subjekwerkwoord-inversie afdwing. 
(103) Finietheid is die plek waar inligting weergegee word wat verband hou met die TP se tempus en geassosieerde onderskeidings (soos byvoorbeeld Modus en, in 'n taal soos Engels, subjek-werkwoord-kongruensie).

Soos getoon in afdeling 3.4, is die bevindings (101b-e) hierbo teenstrydig met die voorstelle van Beninca' \& Poletto (2004). Hoewel dié bevindings nie die essensie van die (aangepaste) Verdeelde-CP-hipotese weerlê nie, dui hulle wel daarop dat die hipotese moontlik aangepas sou kon word om voorsiening te maak vir parametriese verskille tussen tale.

Ten slotte kan daar op drie verdere kwessies gewys word wat verdere ondersoek verg. Die eerste betref die verpligte koreferensiële verhouding tussen 'n getopikaliseerde frase en sy geassosieerde resumptief. Binne die raamwerk van MS bestaan daar tans nie 'n sistematiese beskrywing van hierdie soort verhouding nie; trouens, so 'n beskrywing is ook nie gebied binne die GB-bindingsteorie nie. ${ }^{62}$ Een moontlikheid is om resumptiewe te klassifiseer as anafore wat dan sou beteken dat hulle interpretasie bewerkstellig word deur die volgende interpretatiewe prosedure:

(104) Given a local domain D,

A. if $\alpha$ is an anaphor, interpret it as coreferential with some c-commanding phrase in D. (Chomsky 1995:100)

Beskou byvoorbeeld die sin in (105); die diagram in (106) is 'n vereenvoudigde voorstelling van dié sin se struktuur.

(105) Die skelms, die polisie sal hulle vandag arresteer. 


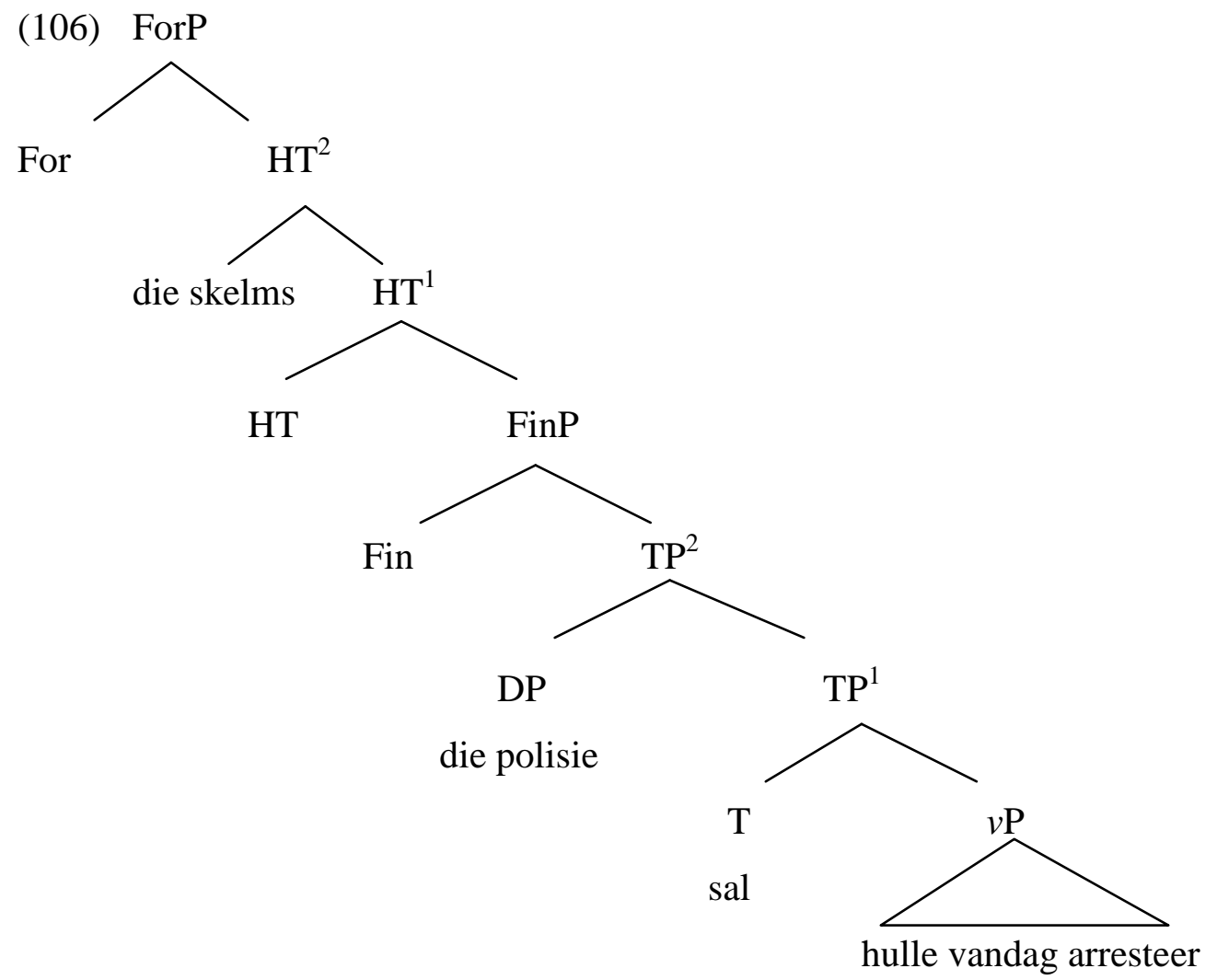

In (106) k-kommandeer die getopikaliseerde frase die skelms sy resumptief hulle. In terme van die prosedure (104) kan die resumptief dus geïnterpreteer word as koreferensieel met sy Topiek-antesedent. So 'n analise is egter problematies in twee opsigte. In die eerste plek sou dit inhou dat die tradisionele klas van anafore - bestaande uit refleksiewe voornaamwoorde soos myself en resiprokale soos mekaar - uitgebrei moet word om alle elemente wat kan optree as resumptiewe in te sluit. Sulke elemente sluit onder meer persoonlike voornaamwoorde, 'n tydsvorm soos toe, en plekvorme soos hier en daar in. In die tweede plek voorspel die interpretatiewe prosedure (104) dat die resumptief in (106) ook die subjek-DP die polisie as antesedent mag neem aangesien hierdie DP ook vir hulle k-kommandeer. Dié voorspelling is egter verkeerd: sin (105) is grammatikaal slegs as daar 'n koreferensiële verhouding bestaan tussen die getopikaliseerde frase en die resumptief.

'n Tweede interessante kwessie betref die inversie van die subjek en die finiete werkwoord in die afleiding van fokuskonstruksies. In afdeling 3.6 is voorgestel dat inversie in sulke gevalle afgedwing word deurdat die Foc-hoof 'n Fin-hoof selekteer wat 'n sterk kenmerk het. Die voorgestelde sterk kenmerk dwing dan die IS van die finiete werkwoord met die Fin-hoof af. Hierdie voorstel is egter problematies omdat dit verkeerdelik voorspel dat inversie verplig 
moet voorkom in fokuskonstruksies. Soos die sinne in $(107 a, b)$ illustreer, is subjekwerkwoord-inversie wel verplig in selfstandige wh-vraagsinne in Afrikaans, maar tog opsioneel in ingebedde wh-vraagsinne soos in $(107 \mathrm{c}, \mathrm{d}) .{ }^{63}$

(107) a. Wat gaan hy eet?

b. *Wat hy gaan eet?

c. [Ek wonder] wat hy gaan eet.

d. [Ek wonder] wat gaan hy eet.

Een moontlike verklaring vir die opsionaliteit van inversie in die afleiding van ingebedde whvraagsinne hou verband met die posisie van die wh-frase binne die CP-domein in sulke sinne. Veronderstel dat 'n werkwoord soos wonder in $(107 \mathrm{c}, \mathrm{d})$ 'n For-hoof selekteer met 'n sterk whkenmerk, en dat die wh-frase direk na die spesifiseerderposisie van die For-hoof skuif om hierdie kenmerk af te merk. Die verkil in woordorde tussen sinne $(107 \mathrm{c}, \mathrm{d})$ kan dan verklaar word in terme van die opsionele seleksie van 'n Foc-hoof deur die For-hoof. Indien die Fochoof nie geselekteer word nie, kan die struktuur onderliggend aan (107d) voorgestel word soos in (108a); indien 'n Foc-hoof wel geselekteer word, kan die struktuur onderliggend aan (107c) voorgestel word soos in (108b). Kortom, in (107c) het fokalisering plaasgevind, maar nie in $(107 d)$ nie.
(108) a. [ForP wat [For [FinP [ gaan [TP hy eet]]]]
(geen Foc-hoof)
b. [ForP wat [For [FocP hy [Foc [FinP [gaan [TP eet]]]]]]
(wel Foc-hoof)

'n Alternatiewe verklaring behels die moontlikhed dat sinne $(107 \mathrm{c}, \mathrm{d})$ albei fokuskonstruksies verteenwoordig. Soos gemeld in afdeling 3.4, maak Beninca' \& Poletto (2004:63) voorsiening vir meer as een hoof binne die Fokus-veld, spesifiek meer as een Inf.Foc-hoof. ${ }^{64}$ Veronderstel nou dat twee sulke hoofde geselekteer is in die afleiding van sin (107c), wat beteken dat daar twee spesifiseerder-posisies beskikbaar is, een vir die wh-frase wat en een vir die DP hy. Beide frases kan dus gefokaliseer wees, soos geïllustreer in (109).

(109) [ForP [ For [ Inf.FocP1 wat [ Inf.Foc [ Inf.FocP2 hy [ Inf.Foc[FinP [ gaan [TP eet]]]]]]]] 
In die afleiding van (107d), daarenteen, is slegs een hoof binne die Fokus-veld geselekteer, wat beteken dat daar slegs een spesifiseerderposisie beskikbaar is; in hierdie geval is die whfrase wat dus gefokaliseer, maar nie die DP hy nie. Soos Beninca' \& Poletto (2004:63) dit egter stel, "More research is needed to enrich the cartography of the Focus field we have just begun to sketch."

'n Derde kwessie wat verdere ondersoek verg betref die aanname dat subjek-werkwoordinversie nooit afgedwing word in strukture wat 'n Top-hoof bevat maar nie 'n Foc-hoof nie. Beskou in hierdie verband weer die voorbeelde in $(35 \mathrm{a}, \mathrm{d})$ in afdeling 3.3.1 hierbo, hier herhaal as $(110 a, b)$.

(110) a. Witwyn, ek kan dit nie drink nie.

b. *Witwyn, kan ek dit nie drink nie.

In afdeling 3.6 is tentatief voorgestel dat 'n Top-hoof 'n Fin-hoof met 'n swak kenmerk selekteer; IS van die Fin-hoof en die finiete werkwoord word dus nie afgedwing nie en die woordorde bly onveranderd. 'n Alternatiewe verklaring vir die afwesigheid van inversie in sinne met 'n getopikaliseerde frase sou egter kon inhou dat fokalisering wel plaasvind in sulke konstruksies maar dat dit nie 'n sigbare effek op die lineêre volgorde van die subjek en die finiete werkwoord het nie. So 'n verklaring sou gegrond kon word op die volgende oorwegings. Eerstens, sover vasgestel kon word, is daar nêrens in die literatuur 'n analise van konstruksies waarin die subjek van ' $\mathrm{n}$ sin gefokaliseer is nie. Dit sou beslis vreemd wees as fokalisering geld vir objekte, adverbiale, ens., maar nie vir subjekte nie. Tweedens, vanuit 'n diskoers-pragmatiese perspektief sou geargumenteer kon word dat uitings wat bedoel is vir die oordrag van inligting uiteraard altyd die een of ander gefokusde element moet bevat, 'n element wat "nuwe" inligting verteenwoordig. Met ander woorde, dit lyk redelik om aan te neem dat die Fokus-veld altyd geaktiveer is en ten minste een Foc-hoof bevat.

Teen hierdie agtergrond sou geargumenteer kon word dat subjek-werkwoord-inversie altyd plaasvind, maar dat die effek daarvan slegs sigbaar is in konstruksies waar nie-subjekelemente gefokaliseer word. Dus, in sin (110a) het fokalisering van die subjek-DP $e k$ wel plaasgevind, asook IS van die finiete werkwoord kan; die effek van hierdie twee bewerkings word egter nie gereflekteer in die oppervlakkige lineêre woordorde nie. Die afgeleide struktuur van sin 
(110a) word weergegee in (111). Let op dat die ongrammatikaliteit van (110b) dan toegeskryf kan word aan die feit dat fokalisering geensins plaasgevind het nie.

(111) [ForP [ For [TopP witwyn [ Top [FocP ek [ Foc [FinP [ kan [TP dit nie drink nie]]]]]]]]

Kortom, daar sou geargumenteer kon word dat elke sin - of dan ten minste elke finiete sin - 'n Foc-hoof bevat wat 'n sterk Fin-hoof selekteer, met die gevolg dat fokalisering altyd plaasvind. 'n Belangrike konsekwensie van dié voorstel is dat subjek-werkwoord-inversie dan nie 'n geldige aanduiding van fokalisering kan wees nie, omdat die effek daarvan nie noodwendig waarneembaar is nie. 'n Sistematiese ondersoek na die meriete van hierdie voorstel, asook van die ander voorstelle hierbo, val egter buite die bereik van hierdie artikel en word gelaat vir verdere studie.

* Hierdie artikel is gebaseer op navorsing wat finansieel ondersteun is deur Die Nasionale Navorsingstigting. Enige opinies, bevindings, gevolgtrekkings of aanbevelings in die artikel is dié van die outeurs, en die NNS aanvaar geen verantwoordelikheid in hierdie verband nie.

\section{Notas}

1. Verskillende soorte D-hoofde is reeds geïdentifiseer, onder meer Kwantifiseerder ("Quantifier", Q), Telwoord ("Numeral", Num), ens.; kyk bv. ook Bernstein (2000), Longobardi (1999) en Radford (2004a).

2. 'n Vroeëre poging in hierdie verband is dié van Hoekstra \& Zwart (1994).

3. Die uiteensetting in afdeling 2.2 is hoofsaaklik gebaseer op Chomsky $(1995,2000)$. Kyk ook bv. Adger (2003), Chomsky (2002), Freidin (1997), Hornstein, Nunes \& Grohmann (2005) en Radford (2004a,b) vir ietwat meer toeganklike besprekings van die aannames en meganismes van MS.

4. Om te sê dat die sintaktiese sisteem skikkings as toevoer gebruik impliseer dat die komputasie-sisteem nie direkte toegang tot die leksikon self het nie. Dit is 'n belangrike punt om in ag te neem in die lig van die eis dat die komputasie-sisteem as geheel so ekonomies moontlik moet werk: as die komputasie-sisteem direkte toegang tot die leksikon het en dié sisteem is optimaal ekonomies, dan sou uitings wat minder leksikale items bevat verkies word bo dié wat meer leksikale items bevat op grond van 
ekonomie en eenvoud. In so 'n sisteem sou die sin Die man slaap bv. "meer grammatikaal" geag moet word as die sin Die man slaap in die bed omdat die eerste sin minder items bevat en dus meer ekonomies is om af te lei. Skikkings oorkom dus die probleem van onder-generasie ("under-generation") wat inherent is aan optimaal ekonomiese sisteme.

5. Kyk Adger (2003:69) en Hornstein et al. (2005:200).

6. Kyk bv. Chomsky (2006:6).

7. Die VP-skulphipotese is aanvanklik voorgestel deur Larson (1988, 1990). Kyk bv. Hornstein et al. (2005:hfst. 3) en Radford (2004a:hfst. 9) vir argumente ter ondersteuning van dié hipotese.

8. Die UTAH is voorgestel deur Baker (1988). Kyk ook bv. Adger (2003:138) en Radford (2004b:338).

9. Let op dat $v$ moontlik leksikaal gevul mag wees in sommige dialekte van Afrikaans; in die uitdrukking Maak staan die paal sou byvoorbeeld geargumenteer kon word dat maak 'n leksikaal gevulde agentiewe ligte werkwoord verteenwoordig.

10. Die uitdrukking "toeken" word hier informeel gebruik; meer presies sou gesê kan word dat $\theta$-rolle uit die struktuur "afgelees" word deur die semantiese komponent wanneer eerstens $\mathrm{V}$ en die objek ES ondergaan, en tweedens $v$ en die subjek ES ondergaan.

11. Kyk bv. Hornstein et al. (2005:hfst. 3), Koopman \& Sportiche (1991) en Radford (2004a:hfst. 7) vir die inhoud en motivering van die PISH (in die literatuur ook bekend as die "VP-internal Subject Hypothesis").

12. Kyk bv. Hornstein et al. (2005:101).

13. Vir die doeleindes van die artikel word aangeneem dat 'n spesifieke $\theta$-rol in 'n spesifieke soort konfigurasie toegeken word, met inagneming van die eienskappe van die betrokke predikaat (in die huidige voorbeeld die V soen); vgl. ook die UTAH hierbo.

14. Die superskrifte 1, 2, ens. het geen teoretiese inhoud nie en word bloot vir verwysingsdoeleindes gebruik.

15. Die item in hoekige hakies $\langle\ldots>$ verteenwoordig die kopie wat ontstaan tydens IS; dié kopie word geskrap in die afleiding van die sin se PF-representasie.

16. Die uitdrukking "(ge)skuif" word voortaan geriefshalwe gebruik vir "Kopieer en Saamvoeg". 
17. In hierdie artikel word aangeneem dat die objek-DP in Afrikaans na die (tweede) spesifiseerderposisie van $v \mathrm{P}^{2}$ skuif vir die doeleindes van kasusafmerking ("Case checking"). Die komplekse $v$ - wat ontstaan deur die saamvoeging van $v$ en die leksikale $\mathrm{V}$ - bevat 'n oninterpreteerbare kasuskenmerk wat afgemerk moet word (kyk bv. Adger 2003:217; Hornstein et al. 2005:par. 9.4.3.1, 10.4.2 ).

18. 'n Verdere moontlike rede vir die verskuiwing van die subjek-DP is dat $\mathrm{T}$ ' $\mathrm{n}$ oninterpreteerbare kasuskenmerk het wat deur die subjek-DP afgemerk moet word; kyk Chomsky (1995:198).

19. Kyk bv. Hornstein et al. (2005:92).

20. Vir die doeleindes van die artikel word aangeneem dat dié sewende stap afgedwing word deur 'n sterk rand-kenmerk ("edge-feature", EF) van die funksionele hoof $v$. 'n Randkenmerk funksioneer soos 'n oorveralgemeende Uitgebreide Projeksie-beginsel: dit vereis dat die spesifiseerderposisie van 'n funksionele hoof minimaal een keer gevul moet word, met geen beperking op die maksimum hoeveelheid kere wat dit gevul mag word nie (kyk Chomsky 2006:6). 'n Verdere aanname wat in hierdie artikel gemaak word, is dat daar in die sintaksis 'n "hiërargie van kenmerke" bestaan. Hiermee word bedoel dat kenmerke wat moontlik betrokke is by die toekenning van $\theta$ rolle, bevredig moet word voor dié wat te doen het met kasusafmerking; laasgenoemde, weer, kry voorrang bo dié wat verband hou met EF. In die afleiding van sin (9), gaan stap (v) dus vooraf aan stap (vi), en stap (vi) vooraf aan stap (vii).

21. Kyk bv. Hornstein et al. (2005:105).

22. Kyk bv. Hornstein et al. (2005:105).

23. Kyk bv. Hornstein et al. (2005:105).

24. Kyk bv. Haegeman (1994:hfst. 2 ) en Ouhalla (1999:hfst. 6) vir 'n uiteensetting van Xbalkteorie.

25. In latere versies van GB-teorie en in Minimalistiese Sintaksis is IP (Infleksiefrase, "Inflection Phrase") vervang met TP (Tempusfrase, "Tense Phrase").

26. In GB-literatuur is gefokaliseerde frases algemeen aangedui met die uitdrukking "getopikaliseerde frases" ("topicalised phrases"). Binne MS word daar sintakties onderskei tussen Topiek ("Topic") en Fokus ("Focus") soos hieronder uiteengesit word. Wat in MS "Topikalisering" genoem word, staan in GB-literatuur bekend as "Links-dislokasie" ("Left Dislocation", LD). LD behels geen verskuiwing nie; die 
aanname is dat die gedislokeerde frase gegenereer word binne die CP. Kyk bv. Radford (1989:530) vir die onderskeiding tussen LD en Topikalisering in GB-teorie.

27. Kyk Radford (1989:303ff.) vir 'n voorstelling van die finietheid-kenmerk van die Choof. Vgl. verder Zwart (1993:161) se voorbeelde van geïnflekteerde C-hoofde, en ook die bespreking in afdeling 3.5 hieronder.

28. V-na-I (ook bekend as "Verb Raising") is 'n bewerking waardeur 'n V-element uit die VP na die I (of T) geskuif word, waarskynlik om 'n tempuskenmerk af te merk. In GBteorie is algemeen aangeneem dat beide I-na-C en Wh-Skuif afgedwing word deur ' $n$ spesifieke kenmerk van die funksionele hoof $\mathrm{C}$, voorgestel as $[+\mathrm{Q}]$ in bv. Ouhalla (1999:71). Kyk bv. Radford (1989:hfst. 8) vir die bewerkings V-na-I en I-na-C. Geriefshalwe word PISH (kyk afd. 2.3) nie in die struktuur (22) geïnkorporeer nie; m.a.w. die subjek word hier voorgestel as die spesifiseerder van die I.

29. In vroeëre versies van GB-teorie is aangeneem dat 'n verskuifde kategorie 'n spoor ("trace") agterlaat in die ontruimde posisie. In latere versies is geargumenteer dat verskuiwing 'n identiese kopie van die betrokke kategorie agterlaat, 'n voorstel wat ook in MS aanvaar word. In (22) en verder word die kopie telkens aangedui tussen hoekige hakies. Kyk bv. Haegeman (1994:309) en Ouhalla (1999:65).

30. Kyk bv. Radford (1989:530) vir die funksie van links-dislokasie.

31. Matthews (1997:320) karakteriseer 'n resumptiewe voornaamwoord "as duplicating the role of a phrase which has the same reference."

32. Kyk vn. 26 vir die gebruik van die term "topikalisering" in GB-teorie; Hoekstra \& Zwart (1994) verwys met dié term eintlik na "fokalisering".

33. Rizzi gebruik asteriske (*) om rekursiwiteit aan te dui.

34. Hoofletters dui fokusklem ("focal stress") aan. Rizzi (1997:285) beweer dat fokusklem noodwendig dui op fokalisering. Volgens Beninca' \& Poletto (2004:56), egter, is fokusklem (wat hulle na verwys as "intonation") nie 'n betroubare aanduiding van fokus nie: "Intonation is not a crucial test for determining the position of an XP: an intonationally focalized element can syntactically be an LD."

35. "Topikalisering" verwys hier na wat in GB-literatuur algemeen bekend gestaan het as "Left Dislocation".

36. Kyk bv. Botha (1995:par. 3.2.1) vir die verskillende funksies van talige kommunikasie. 
37. Vir die doeleindes van die artikel word aangeneem dat resumptiewe voornaamwoorde in Afrikaans ekwivalent is aan "resumptive clitics" in 'n taal soos Italiaans.

38. Kyk ook afdeling 3.1.

39. ModP in (37) staan vir Modaalfrase ("Modal Phrase"), met die modale hulpwerkwoord (Mod) kan as hoof; Mod word aanvanklik na T verskuif om lg. se tempuskenmerk af te merk.

40. Grammatikale ekwivalente van sinne soos die een in (44a) kom klaarblyklik nie voor in Afrikaans nie; vgl. die ongrammatikaliteit van (i) *Gister weet ek wanneer hy gekom het en (ii) *Hier dink ek met wie hy baklei het.

41. Hoekstra \& Zwart (1994:205ff) stel 'n alternatiewe "satelliet-analise" voor wat inhou dat 'n "getopikaliseerde" frase basis-gegenereer word in sy uiteindelike sinsinisiële posisie, en dus nooit skuiwing ondergaan nie. Wat wel skuif, is 'n "lege operator". Dit beteken dat 'n wh-frase en 'n leksikale "getopikaliseerde" frase nie saam sal voorkom nie; die wh-frase kan egter wel saam met 'n leë "Topiek"-operator voorkom. Vir die doeleindes van hierdie artikel word daar nie verder ingegaan op die meriete van so 'n analise nie.

42. Negatiewe kwantifiseerders in Afrikaans (bv. niemand, nêrens, nooit, ens.) kan nie getopikaliseer word nie, ongeag of hulle gemodifiseer is al dan nie. Dit blyk uit die ongrammatikaliteit van sinne soos die volgende:

(i) a. *Niemand van ons buurt, ek het hulle raakgeloop nie.

b. *Niemand, ek het hulle raakgeloop nie.

(ii) a. *Niks wat jy sê, ek sal dit glo nie.

b. *Niks, ek sal dit glo nie.

(On)gemodifiseerde negatiewe kwantifiseerders kan egter wel gefokaliseer word, soos blyk uit die volgende voorbeelde:

(iii) a. Niemand (van ons buurt) het ek raakgeloop nie.

b. Niks (wat jy sê) sal ek glo nie.

43. Kyk bv. Culicover (1997: hfst. 9), Haegeman (1994:417-418) en Ouhalla (1999:240242) vir besprekings van die twee soorte Oorkruising.

44. K-kommandeer ("c(onstituent)-command") word soos volg gedefinieer in Hornstein et al. (2005:78):

A c-commands $\beta$ iff

(i) $\quad \alpha$ does not dominate $\beta$;

(ii) $\quad \beta$ does not dominate $\alpha$;

(iii) the first branching node dominating $\alpha$ also dominates $\beta$; and

(iv) $\quad \alpha$ does not equal $\beta$. 
Die gebruik van indekse om referensiële identiteit uit te druk is nie toelaatbaar binne MS nie. Soos genoem in afd. 2.2, mag daar volgens die Insluitingsvoorwaarde geen inligting bygevoeg word in die loop van 'n afleiding nie; die enigste beskikbare inligting is dié wat verskaf word in die betrokke skikking.

45. Kyk bv. Haegeman (1994:hfst. 4), Hornstein et al. (2005:hfst. 8) en Ouhalla (1999:hfst. 9) vir die verskillende Bindingsbeginsels binne GB-Bindingsteorie.

46. Kyk bv. Haegeman (1994:418).

47. Kyk Oosthuizen \& Waher (1994) vir die struktuur van possessiewe DP's in Afrikaans.

48. Beninca' \& Poletto (2004) bespreek nie die eienskappe van Informatiewe Fokus nie; hulle (2004:63) stel dit bloot dat dié tipe Fokus voorkom in "positions lower than the Contrastive Focus position". Dit is interessant om daarop te let dat, volgens hierdie aanhaling, voorsiening gemaak word vir meer as een Informatiewe Fokus-posisie.

49. Let op dat die volgorde van die resumptiewe elemente in (63) presies dieselfde is as die volgorde in (62). Die omgekeerde resumptief-volgorde is klaarblyklik onaanvaarbaar:

(i) a. *Gister, met Marie, ek het met haar toe gesels.

b. * Met Marie, gister, ek het met haar toe gesels.

'n Analise van die relatiewe volgorde van resumptiewe elemente val egter buite die bereik van hierdie artikel.

50. Soos genoem in vn. 37 word hier aangeneem dat resumptiewe voornaamwoorde in Afrikaans ekwivalent is aan "resumptive clitics" in 'n taal soos Italiaans.

51. Die dubbele Cont.Foc-projeksie van Beninca' \& Poletto (2004) word geriefshalwe nie hier weergegee nie.

52. Na aanleiding van die bogenoemde voorstelle van Rizzi (1997:325) word hier aangeneem dat die komplementeerders dat, of en om Krag-hoofde in Afrikaans is. In (82) word die Fin-hoof dus telkens aangedui as 'n koverte element.

53. Rizzi se analise is voorafgegaan deur enkele ander studies, waaronder Den Besten (1977) en Hoekstra \& Zwart (1994); kyk ook Oosthuizen (1994).

54. Die seleksie van óf 'n Kontrastiewe Fokus-hoof óf 'n Informatiewe Fokus-hoof hang saam met die voorafgaande konteks. Die Cont.Foc-hoof in (84) dui dus aan dat daar vroeër oor wyn gepraat is, maar nie oor rooiwyn spesifiek nie; kyk ook afdeling 3.4 hierbo. Hier en verder word aangeneem dat die koverte Krag-hoof ("For") spesifiseer of die sin 'n stelsin, vraagsin, ens. is; kyk afdeling 3.5 in dié verband. 
55. Die presiese aard van so 'n sterk kenmerk van die Fin-hoof is onduidelik. In die literatuur word daar geen aanduiding gegee of dit die kenmerk [+ Finiet] self is, en of dit dalk 'n ander soort funksionele kenmerk is nie.

56. Die opmerkings in vn. 55 geld ook vir die voorgestelde swak kenmerk van die Finhoof wat deur 'n Topiek-hoof geselekteer word.

57. In afd. 3.4 is die gevolgtrekking gemaak dat verskuifde wh-frases altyd in die spesifiseerderposisie van Inf.Foc. voorkom.

58. In Afrikaans is dit ook moontlik om meer as een getopikaliseerde element in die Topiek-veld te hê. In afd. 3.4 is aangetoon dat daar nie 'n beperking is op die lineêre volgorde van HT's en LD's nie. LD's kan egter nie sonder HT's voorkom nie, terwyl HT's nie onderhewig is aan so 'n beperking nie. Dit is verder moontlik om meer as een HT te kry, maar nie meer as een LD nie. Gevolglik kan die HT en LD in enige volgorde voorkom in (92) sonder om die grammatikaliteit van die sin te beïnvloed. In verband met die beperking op die voorkoms van LD's, sou daar geargumenteer kon word dat 'n HT-hoof 'n kenmerk bevat wat óf nog 'n HT óf 'n LD kan selekteer as komplement, terwyl LD-hoofde nie 'n ooreenstemmende kenmerk bevat nie.

59. Beninca' \& Poletto (2004:61) stel dit dat "There must be at least two Contrastive Focus projections available in the CP structure: one hosting adverbs or objects, and one devoted to circumstantial and quantificational adverbs."

60. Beninca' \& Poletto (2004:63-70) suggereer twee verdere hoofde binne die Topiekveld, naamlik Toneelskets en Lys-interpretasie, sonder om in besonderhede in te gaan op die eienskappe van dié hoofde. Soos gemeld in afdeling 3.4 word hierdie tentatiewe suggesties nie verder ondersoek in hierdie artikel nie.

61. Kyk vn. 59 asook afdeling 3.4.

62. Kyk bv. Chomsky $(1981$; 1982) en Haegeman (1994) vir die beginsels van GBbindingsteorie.

63. In afd. 3.4 is geargumenteer dat vooropgestelde wh-frases instansies van Inf.Foc is. Kyk ook Oosthuizen (1996) vir 'n beskrywing van die verskynsel in (107) binne die raamwerk van Hoekstra \& Zwart (1994) se onderskeiding tussen TopP en WhP binne die CP-domein.

64. Kyk ook vn. 59. 


\section{Verwysings}

Abney, S. 1987. The English noun phrase in its sentential aspect. Dissertation, Massachusetts Institute of Technology. Distributed by MIT Working Papers in Linguistics.

Adger, D. 2003. Core syntax: A minimalist approach. Oxford: Oxford University Press.

Baker, M. 1988. Incorporation. Chicago: University of Chicago Press.

Beninca', P. \& C. Poletto. 2004. Topic, Focus and V2: Defining the CP sublayers. In Rizzi, L. (ed.) 2004. The cartography of syntactic structures, volume 2: The structure of CP and IP. New York: Oxford University Press.

Bernstein, J. 2000. The DP hypothesis: Identifying clausal properties in the nominal domain. In Baltin, M. \& C. Collins (eds). 2000. Handbook of contemporary syntactic theory. Oxford/Cambridge: Basil Blackwell.

Botha, R.P. 1995. The world of language: A Carrollinian canvas. Stellenbosch Papers in Linguistics (SPIL) 29.

Bresnan, J. 1970. On Complementizers: toward a syntactic theory of complement types. Foundations of language 6 (3): 297-321.

Bresnan, J. 1974. The position of certain clause-particles in phrase structure. Linguistic Inquiry 5 (4): 614-619.

Bresnan, J. 1977. Transformations and categories in syntax. In Butts, R. \& J. Hintikka (eds). 1977. Basic problems in methodology and linguistics. Dordrecht: D. Reidel Company.

Chomsky, N. 1972. Studies on semantics in generative grammar. The Hague: Mouton.

Chomsky, N. 1981. Lectures on government and Binding. Dordrecht: Foris.

Chomsky, N. 1982. Some concepts and consequences of the theory of government and binding. Cambridge, Mass.: MIT Press.

Chomsky, N. 1995. The minimalist program. Cambridge, Mass.: MIT Press.

Chomsky, N. 2000. Minimalist inquiries: The framework. In Martin, R., D. Michaels \& J. Uriagereka (eds). 2000. Step by step: Essays on minimalist syntax in honor of Howard Lasnik. Cambridge, Mass.: MIT Press.

Chomsky, N. 2002. On nature and language. Cambridge: Cambridge University Press.

Chomsky, N. 2006. Approaching UG from below. Manuscript of a paper read at a conference in Berlin, Germany, April 2006.

Culicover, P. 1997. Principles and parameters: An introduction to syntactic theory. New York: Oxford University Press. 
Den Besten, H. 1977. On the interaction of root transformations and lexical deletive rules. In Den Besten, H. 1989. Studies in West Germanic syntax. Dissertation. Amsterdam: Rodopi.

Emonds, J. 1976. A transformational approach to English syntax: root, structure-preserving and local transformations. New York: Academic Press.

Freidin, R. 1997. Review article: The minimalist program. Language 73 (3): 571-582.

Gundel, K. \& T. Fretheim. 2004. Topic and focus. In Horn, L. \& G. Ward (eds). The handbook of pragmatics. Cambridge, Mass.: Basil Blackwell.

Haegeman, L. 1994. Introduction to government and binding theory ( $2^{\text {nd }}$ edition). Cambridge, Mass.: Basil Blackwell.

Hoekstra, E. \& J-W. Zwart. 1994. De structuur van de CP. Spektator 23(3): 191-212.

Hornstein, N., J. Nunes \& K. Grohmann. 2005. Understanding minimalism. Cambridge: Cambridge University Press.

Jackendoff, R. 1977. X' Syntax: A study of phrase structure. Cambridge, Mass.: MIT Press.

Koopman, H. \& D. Sportiche. 1991. The position of subjects. Lingua 85: 211-258.

Larson, R. 1988. On the double object construction. Linguistic Inquiry 19: 335-391.

Larson, R. 1990. Double objects revisited: reply to Jackendoff. Linguistic Inquiry 21: 589632.

Longobardi, G. 1999. The structure of DPs: some principles, parameters and problems. In Baltin, M. \& C. Collins (eds). 2000. Handbook of contemporary syntactic theory. Oxford/Cambridge: Basil Blackwell.

Matthews, P. 1997. The concise Oxford dictionary of linguistics. New York: Oxford University Press.

Oosthuizen, J. 1994. 'n Verdere komplement vir COMP. In Van der Merwe, C., H. Waher \& J. Hambidge (reds.). Rondom Roy: Studies opgedra aan Roy H. Pheiffer. Departement Afrikaans en Nederlands, Universiteit Kaapstad.

Oosthuizen, J. 1996. Minimalisme en woordordevariasie in Afrikaanse vraagsinne. Stellenbosch Papers in Linguistics (SPIL) 29: 71-98.

Oosthuizen, J. \& H. Waher. 1994. On the syntax of the se-construction in Afrikaans. Stellenbosch Papers in Linguistics (SPIL) 28:21-44.

Ouhalla, J. 1999. Introducing transformational grammar: From principles and parameters to minimalism ( $2^{\text {nd }}$ edition). New York: Oxford University Press. 
Pollock, J-Y. 1989. Verb movement, universal grammar, and the structure of IP. Linguistic Inquiry 20(3): 365-424.

Radford, A. 1989. Transformational Grammar: A First Course. Cambridge: Cambridge University Press.

Radford, A. 2004a. English syntax: An Introduction. Cambridge: Cambridge University Press.

Radford, A. 2004b. Minimalist syntax: Exploring the structure of English. Cambridge: Cambridge University Press.

Rizzi, L. 1997. The fine structure of the left periphery. In Haegeman, L. (ed.) 1997. Elements of grammar: Handbook in generative syntax. Dordrecht: Kluwer Academic Publishers.

Rizzi, L. 2004. On the cartography of syntactic structures. In Rizzi, L. (ed.) 2004. The cartography of syntactic structures, volume 2: The structure of CP and IP. New York: Oxford University Press.

Zwart, J-W. 1993. Dutch syntax: A minimalist approach. Groningen: Universiteitsdrukkerij Groningen. 